\title{
Whither China? Reform and economic integration among Chinese regions ${ }^{2}$
}

\author{
Shuo HUANG a, Jan FIDRMUC ${ }^{\text {b,ce,f,*, }, \text { Jarko FIDRMUC }}{ }^{\text {d,e,f }}$ \\ a Southwestern University of Finance and Economics, China \\ b Department of Economics and Finance, Brunel University, UK \\ c CEDI, Brunel University, UK \\ d Zeppelin University Friedrichshafen, Germany \\ e CESIfo Munich, Germany \\ ${ }^{\mathrm{f}}$ Institute of Economic Studies, Charles University, Czech Republic
}

\section{A R T I C L E I N F O}

\section{Article history:}

Received 13 August 2013

Received in revised form 22 December 2014

Accepted 22 December 2014

Available online 31 December 2014

\section{JEL classification:}

E32

F15

H77

Keywords:

SVAR model

Business cycle synchronization

China

Economic reform

\begin{abstract}
A B S T R A C T
This paper investigates the changing nature of economic integration in China. Specifically, we consider business-cycle synchronization (correlation of demand and supply shocks) among Chinese provinces during the period 1955-2011. We find that the symmetry of supply shocks has declined after the liberalization initiated in 1978. In contrast, the correlation of demand shocks has increased during the same period. We then seek to explain these correlations by relating them to factors that proxy for interprovincial trade and vulnerability of regions to idiosyncratic shocks. Interprovincial trade and similarity in factor endowments tend to make shocks more symmetric. Surprisingly, foreign trade and inward FDI have little effect on the symmetry of shocks.

(C) 2015 The Authors. Published by Elsevier Inc. This is an open access article under the CC BY license
\end{abstract} (http://creativecommons.org/licenses/by/4.0/).

\section{Introduction}

Since 1978, China has been undertaking a gradual and largely steady liberalization. The changes were especially profound in the economic sphere although, lately, they have extended also to the political domain. The three decades of economic liberalization have had far-reaching effects on the Chinese economy and society. China has maintained a high rate of growth, recently becoming the second largest economy in the world. Yet, the benefits of this expansion have not been universally shared. Most notably, the coastal provinces of Eastern and South-Eastern China have charged ahead while the inland provinces have lagged behind. There is a similar, though less pronounced, disparity between urban centers and their rural hinterlands throughout China. These regional disparities

\footnotetext{
is We benefited from the comments and suggestions received at the presentations at Brunel University, Bank of Finland, Southwestern University of Finance and Economics in Chengdu, Northwestern University in Xi'An, University of International Business and Economics in Beijing, CESifo Venice Summer Institute, the China meeting of the Econometric Society as well as Ying Deng, Ikka Korhonen, Rong Kang and two anonymous referees. This research was in part carried out while Jan Fidrmuc and Shuo Huang were visiting the Bank of Finland Institute for Economies in Transition (BOFIT), whose hospitality and financial support are gratefully acknowledged.

* Corresponding author at: Department of Economics and Finance, and Centre for Economic Development and Institutions (CEDI), Brunel University, Uxbridge UB8 3PH, UK. Tel.: + 441895266528

E-mail addresses: Jan.Fidrmuc@brunel.ac.ik, jan@fidrmuc.net (J. Fidrmuc).
} 
reflect not only differentiated economic regional development but are also further reinforced by the continued implementation of the hukou system of household registration which restricts labor and residential mobility. ${ }^{1}$

The large regional economic differentials appear on the background of a high degree of economic decentralization. This is highlighted by Xu (2010) who describes China as a regionally decentralized authoritarian system. He points out that while the central government controls the key political appointments at all levels, it allows regional governments to run their economic affairs largely unimpeded. This, he argues, has emerged as a product of political upheavals and purges during the Great Leap Forward and, especially, the Cultural Revolution. During these turbulent periods, the Soviet-inspired centralized model was abandoned and instead the regions were encouraged to compete with each other. The resulting inter-regional competition was aimed primarily at maximizing output but it also fostered experimentation with respect to production arrangements and policies. This decentralization continued and was even reinforced during the reform period. Arguably, a particularly dramatic step in this direction was the creation of the special economic zones (SEZs) in the early years of liberalization. ${ }^{2}$ This effectively introduced a two-speed system, allowing selected regions to charge ahead in economic liberalization while the rest of the Chinese economy proceeded more cautiously. In turn, this laid the foundations of the subsequent economic gaps between the coastal areas and the rest of the country. ${ }^{3}$

In this paper, we document the depth of economic integration among Chinese provinces and analyze the factors that foster such integration. Our analysis proceeds in two steps. First, we use a structural vector auto-regressive (SVAR) model to identify provincespecific shocks between 1955 and 2011. ${ }^{4}$ Our methodology allows us to distinguish between shocks that have a temporary vs permanent effect on output, typically referred to as demand and supply shocks, respectively. We compute the correlations between these shocks for all pairs of provinces for four sub-periods: two before and two after the 1978 liberalization. These correlations capture the intensity of integration, and the changes therein, among China's provinces over a period during which the country gradually abandoned central planning, state ownership as well as Maoism. Second, we analyze the determinants of these correlations using a stylized version of the gravity model (broadly in line with Artis and Okubo (2010 and 2011), although they use a different methodology for estimating business-cycle correlations). In particular, we seek to explain the correlations of shocks by relating them to the factors that proxy for the vulnerability of regions to idiosyncratic shocks, and the factors that can facilitate inter-regional transmission of the effects of such shocks. The latter include endowments of physical and human capital, transport infrastructure, structure of the economic activity, openness to foreign trade, foreign direct investment, geography, and economic policy. We also include variables that are likely to be correlated with inter-provincial trade. This analysis is carried out for the same four sub-periods so as to capture the determinants of economic integration in the various periods, and the changes therein.

Our main findings are the following. First, the demand and supply shocks have evolved differently in the course of the Chinese reforms: demand shocks appear to have become more synchronized over time while supply shocks have grown more dissimilar. Second, we find that factors that proxy for interprovincial trade and account for the similarity in factor endowments tend to make shocks more symmetric. Rather surprisingly, foreign trade and inward FDI have had little effect on the symmetry of shocks.

The remainder of the paper is structured as follows. The next section briefly discusses what we know about economic integration and decentralization in China. Section 3 describes the data and empirical methodology. Section 4 reports the main empirical finding and Section 5 states the conclusions.

\section{China's economic integration}

\subsection{Economic decentralization under Mao and Deng}

During the period from the communist takeover in 1949 until 1978, the Chinese economy was tightly regulated: output quotas, resource allocations and prices were set centrally according to a plan formulated by the central government. This reflected the initial desire of Mao Zedong's government to follow the Soviet model of organizing the economy. However, as argued by Xu (2010), China started to deviate from the Soviet model during the economic and political upheavals of the Great Leap Forward (1958-1961) and Cultural Revolution (1966-1976). Rather than plan and regulate the economic activity from the center, the central government granted wide-ranging economic autonomy to the provincial governments. This was to encourage the regions to compete with each other in order to deliver or exceed their quota of output. As a result, China became a collection of regional economies rather than a single centrally-planned Soviet-type economy, with the central government in Beijing retaining control over political appointments and decisions while devolving much of economic policy making to the provinces.

The decentralization accelerated further after Mao's death in $1976 .{ }^{5}$ The objective was to reinvigorate the stagnant economy by improving incentives and encouraging local initiative in the production (Tang, 1998). The fiscal and economic decentralization has

\footnotetext{
1 More precisely, the hukou system divides the population into urban and rural residents, and restricts the access of rural residents to public services including healthcare, education, pension insurance and unemployment insurance in case they move to urban regions.

2 On the history of SEZs and the role they have played in Chinese economic development, see Chen, Goh, Sun, and Xu (2011), and the references therein.

${ }^{3}$ An especially poignant example of the fruits of this policy is Shenzhen, a city in Guangdong, whose population exploded from around 300,000 to its current 14 million since it became the first special economic zone more than 30 years ago.

4 The use of structural VARs to assess the intensity of economic integration between countries or regions was pioneered by Bayoumi and Eichengreen (1993) whose work was in turn motivated by the Theory of Optimum Currency Areas (henceforth OCA; Mundell, 1961). Bayoumi and Eichengreen applied this methodology to assess the merits of adopting the common currency in the European Union. They sought to identify which European countries encounter shocks that are predominantly symmetric or asymmetric in nature, as the OCA theory suggests that monetary integration is less costly if it involves countries that are subject to symmetric shocks. Since their seminal contribution, this method has been used for assessing other countries or integration projects as well, see Fidrmuc and Korhonen (2003, 2006), de Haan, Inklaar, and Jong-A-Pin (2008a), and the references therein.

${ }^{5}$ For example, the central government's share of expenditures declined from 51\% in 1978 to 28\% in 1993 (Ma and Norregaard, 1998).
} 
been widely acknowledged as one of the key drivers of the fast growth of the Chinese economy in the last three decades. However, it has also allowed some local governments to implement protectionist policies, ostensibly with the objective to develop their local economies (Bai, 1981).

Another important change that took place after Mao's death was the liberalization of the economy. This was initiated by Deng Xiaoping in 1978 and was designed to be gradual not only with respect to time but also in space. Initially, the liberalization favored the coastal regions and fostered their development ahead of the rest of the country. Most notably, the central government directed foreign investment to a handful of SEZs, all of which were located on the cost. In effect, the SEZs were allowed to be increasingly driven by market forces while central planning remained in force in the rest of the country. After the SEZs proved successful, liberal policies were gradually extended beyond them, first throughout the coastal provinces and later throughout all of China. This helped stimulate the rapid development of the coastal regions and increased their competitiveness compared to the interior (Poncet, 2005). At the same time, the inland provinces continued to export raw materials to the coastal areas at fixed (low) prices, which translated to a net transfer of resources from the interior regions to the manufacturing provinces on the coast. The less developed regions responded by pursuing a policy of industrialization through import substitution, as decentralization combined with the fact that most of the tax revenue accrued from industrial production made them keen to develop their industrial base (Lee, 1998; Poncet, 2005).

An important element of the Maoist regime was the household registration ( hukou) system, which severely restricts the ability of Chinese citizens to move and even travel within China. Under this system, each person was tied to a particular area and could move to a different area only with the permission of the authorities of both origin and destination regions. Despite progressively accelerating economic liberalization, the hukou system has remained in place even after 1978. Unlike during the Maoist period, rural workers now can move to and take up jobs in the urban areas. However, changing their hukou to the destination region remains difficult. This means that they can only receive public services in their region of origin: health care eligibility, children's education and pension claims, most notably, are not portable. Despite this, labor mobility has been steadily increasing, especially from the inland rural to coastal urban regions (Tang, 1998).

In all, China is an economy with a single currency but capital or labor are not perfectly mobile. Its provinces are subject to centralized political rule but are growing more and more decentralized on the economic front.

\subsection{Asymmetric shocks in China}

How well integrated is the Chinese economy? A common approach for assessing the intensity of integration is based on examining the similarity of business cycles. Compared with other approaches, the business-cycle approach has several advantages. It not only provides a comprehensive measure of the various factors that contribute to economic integration but it can reveal also whether there are any regional groups of the provincial economies that are highly integrated (Tang, 1998).

A number of approaches have been utilized to assess the degree of asymmetry of shocks across economies. When analyzing the integration of the Chinese economy, methodological approaches initially developed in the international context are often applied in inter-regional context as well. ${ }^{6}$ One method is based on considering correlations of growth rates, inflation rates, exchange rates, interest rates and/or stock prices. The weakness of this method is that it does not allow one to distinguish between the shocks themselves and the reactions to them. For example, Poncet and Barthèlemy (2008) investigate business cycles and their determinants by identifying the cyclical component of monthly provincial gross output over 1991-2004. They find that despite a cleavage existing between the coastal and interior regions, business-cycle synchronization increased from a rather low level at the beginning of the 1990s to a level comparable to that of the U.S. at the beginning of the 2000s. Furthermore, they argue that international trade and local economic policy foster synchronization. However, Herrmann-Pillath, Libman, and Yu (2010) argue that this finding may be attributable to the specific macroeconomic environment during the period analyzed and as such it cannot be generalized into the future.

Another popular method is to identify shocks using the SVAR model, as put forward by Blanchard and Quah (1989). This model allows the analyst to identify both shocks and the economic responses to them. This method has become a popular tool for identifying asymmetric shocks since it was applied by Bayoumi and Eichengreen (1993) to assess the similarities of economic cycles in Europe in the run-up to the formation of the European Economic and Monetary Union (Babetskii, 2005). The SVAR methodology allows one to distinguish between shocks that affect both output and price level permanently (supply shocks) and those affecting output only temporarily while having a permanent price-level effect (demand shocks). The literature studying the business-cycle synchronization of the Chinese economy using the SVAR method remains very limited, however. Tang (1998) adopts this model to gauge the degree of economic integration within China using data on industrial output and the retail price index. He argues that a high degree of integration prevails in Eastern China only. This finding has been also replicated by Poncet and Barthèlemy (2008).

Gerlach-Kristen (2009) uses a different methodology: she identifies the common component in output gap fluctuations at the provincial level by using principal component analysis. She finds that the degree of synchronization varies over time: while it was high

\footnotetext{
${ }^{6}$ Since the international and intra-national contexts are fundamentally different, although we follow this approach as well, we cannot draw direct comparisons between results that we obtain in inter-regional analysis of China with those obtained with international data. We are grateful to a referee for pointing this out.
} 
Table 1

Average provincial real GDP and growth rate, East.

\begin{tabular}{|c|c|c|c|c|c|}
\hline Provinces & & 1955-1965 & 1966-1977 & 1978-1991 & 1992-2011 \\
\hline \multirow[t]{2}{*}{ Beijing } & GDP & 36.93 & 76.70 & 238.30 & 1432.51 \\
\hline & growth & $6.53 \%$ & $8.85 \%$ & $9.22 \%$ & $11.07 \%$ \\
\hline \multirow[t]{2}{*}{ Tianjin } & GDP & 27.02 & 50.97 & 139.74 & 957.59 \\
\hline & growth & $6.58 \%$ & $5.94 \%$ & $8.47 \%$ & $13.76 \%$ \\
\hline \multirow[t]{2}{*}{ Shanghai } & GDP & 95.55 & 199.93 & 555.74 & 3454.18 \\
\hline & growth & $7.92 \%$ & $7.27 \%$ & $8.00 \%$ & $11.79 \%$ \\
\hline \multirow[t]{2}{*}{ Liaoning } & GDP & 99.16 & 176.40 & 483.82 & 2575.72 \\
\hline & growth & $5.25 \%$ & $7.55 \%$ & $8.17 \%$ & $11.24 \%$ \\
\hline \multirow[t]{2}{*}{ Shandong } & GDP & 61.41 & 125.05 & 416.32 & 3550.36 \\
\hline & growth & $3.56 \%$ & $7.84 \%$ & $10.29 \%$ & $13.28 \%$ \\
\hline \multirow[t]{2}{*}{ Jiangsu } & GDP & 59.28 & 109.52 & 394.49 & 3623.28 \\
\hline & growth & $4.38 \%$ & $4.01 \%$ & $9.28 \%$ & $12.24 \%$ \\
\hline \multirow[t]{2}{*}{ Zhejiang } & GDP & 39.20 & 63.69 & 256.24 & 2356.09 \\
\hline & growth & $5.22 \%$ & $4.68 \%$ & $12.84 \%$ & $13.25 \%$ \\
\hline \multirow[t]{2}{*}{ Fujian } & GDP & 23.09 & 36.36 & 131.56 & 1293.00 \\
\hline & growth & $5.64 \%$ & $4.93 \%$ & $12.13 \%$ & $13.79 \%$ \\
\hline \multirow[t]{2}{*}{ Guangdong } & GDP & 47.08 & 79.52 & 269.66 & 2769.64 \\
\hline & growth & $4.65 \%$ & $4.93 \%$ & $12.20 \%$ & $13.25 \%$ \\
\hline
\end{tabular}

GDP is average provincial GDP over the period in 100 million Yuan.

Sources: 'Comprehensive Statistical Data and Materials 50 years of New China', China Labour Statistical Yearbook and provincial statistical books.

during the 1960s, it declined during the 1970s and 1980s and then rose again. Her results indicate, furthermore, that business cycles in the inland provinces in Northern and Northeastern China tend to be less influenced by the national business cycle.

In summary, the evidence so far, as limited as it is, suggests that the Chinese provincial business cycles have become more synchronized over time but this process has not been uniform. In particular, a gap may be emerging between the coastal and interior regions, with the former becoming more integrated over time, unlike the latter.

\subsection{Determinants of business-cycle co-movements}

There is no consensus as to which determinants of business-cycle co-movement are important. There are instead many potential candidate explanations of business-cycle synchronization or the lack thereof. One leading candidate is trade. Frankel and Rose (1998) show empirically that higher bilateral trade between two countries leads to greater correlation of business cycles between them. An opposite view is put forward by Krugman (1993) who argues that international trade increases specialization, making shocks more asymmetric. Frankel and Rose (1998) argue that inter-industry and intra-industry trade play different roles in this respect. The former reflects specialization and therefore may cause asymmetries. The latter implies that the country simultaneously exports and imports products of the same category. The total effect of trade intensity on business-cycle correlation is therefore theoretically ambiguous and the question can only be answered empirically. Fidrmuc (2004) adopts the approach of Frankel and Rose (1998) and applies it to a cross section of OECD countries over the last ten years with quarterly data, controlling for intra-industry trade in his analysis. His findings confirm the Frankel and Rose view. Baxter and Kouparitsas (2005), similarly, argue that trade is the only factor with a robust effect on business cycle synchronization. In contrast, de Haan, Inklaar, and Jong-A-Pin (2008b) posit that the role of trade is less important than suggested by this literature.

However, trade and business cycle correlation may be endogenous. Therefore, many studies use instruments taken from gravity models to identify the relationship between business cycles and trade. Alternatively, one can include the instruments directly in the regression equation. The gravity model relates bilateral trade flows to variables such as distance between regions, common language, common border, and so on. Therefore, gravity-model variables can be, in turn, used as proxies for trade and therefore can be used as determinants of business-cycle synchronization: see, among others, Clark and van Wincoop (2001), Calderon, Chong, and Stein (2007) and Fidrmuc (2004).

Imbs $(1998,2003,2004)$ and others point out the positive relationship between similarity in the structure of output and businesscycle synchronization. The presence of this relationship was confirmed in empirical analyses using regional data by Kalemli-Ozcan, Sorensen, Reshef, and Yosha (2001) and Clark and van Wincoop (2001). Kalemli-Ozcan et al. (2001), in particular, find that U.S. states that are more specialized in turn display a lower correlation of business cycles with the aggregate U.S. growth.

Fatás (1997) argues that the coordination of monetary and fiscal policies is a key determinant of business-cycle synchronization. He points out that it has an ambiguous impact on business cycles since it depends on the type of shocks driving economic fluctuations and the ability of governments to stabilize output. If macroeconomic policies are the source of business cycles, more coordinated policy could lead to higher synchronization. Darvas, Rose, and Szapary (2005) and Artis, Fidrmuc, and Scharler (2008) investigate and confirm this based on the European Union data while Poncet and Barthèlemy (2008) and Lan and Sylwester (2010) obtain similar findings with Chinese regional data.

Furthermore, factor endowments also drew attention of scholars. Most theories, such as the Heckscher-Ohlin model, Ricardian theories and models with differentiated products, predict a significant relationship among factor endowments and business-cycle co-movement. 
Table 2

Average provincial real GDP and growth rate, Center.

\begin{tabular}{|c|c|c|c|c|c|}
\hline Provinces & & 1955-1965 & 1966-1977 & 1978-1991 & 1992-2011 \\
\hline \multirow[t]{2}{*}{ Hebei } & GDP & 54.21 & 99.76 & 308.50 & 2198.00 \\
\hline & growth & $3.22 \%$ & $7.95 \%$ & $9.07 \%$ & $12.15 \%$ \\
\hline \multirow[t]{2}{*}{ Shanxi } & GDP & 32.87 & 50.39 & 139.63 & 726.65 \\
\hline & growth & $6.19 \%$ & $4.31 \%$ & $8.58 \%$ & $10.95 \%$ \\
\hline \multirow[t]{2}{*}{ Inner-Mongolia } & GDP & 26.49 & 39.23 & 111.49 & 810.98 \\
\hline & growth & $5.96 \%$ & $3.96 \%$ & $9.48 \%$ & $13.73 \%$ \\
\hline \multirow[t]{2}{*}{ Jilin } & GDP & 29.04 & 49.16 & 133.00 & 787.42 \\
\hline & growth & $5.94 \%$ & $4.70 \%$ & $8.98 \%$ & $11.96 \%$ \\
\hline \multirow[t]{2}{*}{ Heilongjiang } & GDP & 49.40 & 89.47 & 203.39 & 902.02 \\
\hline & growth & $6.24 \%$ & $5.40 \%$ & $7.11 \%$ & $10.11 \%$ \\
\hline \multirow[t]{2}{*}{ Anhui } & GDP & 28.77 & 45.34 & 111.86 & 729.74 \\
\hline & growth & $3.04 \%$ & $4.43 \%$ & $7.86 \%$ & $12.77 \%$ \\
\hline \multirow[t]{2}{*}{ Jiangxi } & GDP & 26.36 & 41.23 & 107.76 & 712.47 \\
\hline & growth & $4.38 \%$ & $4.01 \%$ & $9.28 \%$ & $12.24 \%$ \\
\hline \multirow[t]{2}{*}{ Henan } & GDP & 42.33 & 76.36 & 231.06 & 1513.67 \\
\hline & growth & $1.67 \%$ & $6.10 \%$ & $9.88 \%$ & $12.08 \%$ \\
\hline \multirow[t]{2}{*}{ Hunan } & GDP & 42.93 & 71.90 & 188.23 & 1030.73 \\
\hline & growth & $4.36 \%$ & $5.82 \%$ & $8.33 \%$ & $11.49 \%$ \\
\hline \multirow[t]{2}{*}{ Hubei } & GDP & 41.81 & 64.54 & 196.95 & 1265.32 \\
\hline & growth & $7.21 \%$ & $4.57 \%$ & $9.53 \%$ & $12.31 \%$ \\
\hline
\end{tabular}

GDP is average provincial GDP over the period in 100 million Yuan.

Sources: 'Comprehensive Statistical Data and Materials 50 years of New China', China Labour Statistical Yearbook and provincial statistical books.

\section{Supply and demand shocks}

\subsection{Chinese provincial data}

China is administratively divided into 31 regions: 22 provinces, 5 autonomous ethnic-minority regions (Tibet, Xinjiang, Guanxi, Ningxia and Inner Mongolia) ${ }^{7}$ and 4 metropolitan provinces (Beijing, Shanghai, Tianjin and Chongqing). For simplicity, we refer to all of them as provinces in the remainder of the paper. Our sample covers 28 provinces for which data are available. ${ }^{8}$ Annual data are available for the period from 1952 to 2011. Provincial real GDP growth and the GDP deflator are obtained from nominal and real GDP indexes published by the Bureau of National Statistics of China. ${ }^{9}$ We test all variables for unit roots using the Augmented and GLS Dickey-Fuller tests and obtain clear rejections of the null of unit root for first differences of output and prices for all provinces. $^{10}$

We subdivide the sample into three geographical regions: East, Center and West. Besides reflecting geography, this categorization also broadly captures the differences in the degree of economic development. During the early transition period, the coastal areas in the East were the main beneficiaries of the open door policy, developing much more quickly than the interior areas in the Center and West. This regional break-down is confirmed by Herrerias and Ordoñez (2012) who identify convergence clubs among Chinese provinces with respect to income per capita, labor productivity and capital intensity: although their research yields five clubs, their borders approximately overlap with the three regions that we use. Furthermore, we divide the period covered by the data into four sub-periods: 1955-1965, 1966-1977, 1978-1991 and 1992-2011. This break-down reflects the main phases of China's economic and political development. The first two sub-periods correspond to the early and late Maoism. The early Maoist period includes the Great Leap Forward (1958-1961) while the late Maoist period coincides with the Cultural Revolution (1966-1976). The economic liberalization was initiated in 1978. It accelerated further following Deng Xiaoping's Southern Tour in 1992. We therefore treat this year as the start of a new phase of China's reform process (see also Fleisher, Li, and Zhao (2009); $\mathrm{Xu}$ (2007)). Tables 1-3 report some basic statistics on the three regions and the four sub-periods.

\subsection{Identification of shocks}

In this subsection, we present the methodology used to identify province-specific structural shocks. We use a SVAR model with two variables: the log-difference of output (annual real GDP) and the log-differences of prices (annual GDP deflator), $\mathbf{Y}=\left(\Delta G D P_{t}, \Delta P_{t}\right)^{\prime}$. It is assumed that the fluctuations in these two variables result from two types of disturbances: supply and demand shocks. This terminology

\footnotetext{
${ }^{7}$ Autonomous regions are those with a high share of a particular ethnic minority: Tibetans (Tibet), Uyghurs (Xinjiang), Zhuangs (Guangxi), Huis (Ningxia) and Mongols (Inner Mongolia). According to the Chinese constitution, autonomous regions should enjoy more legal autonomy although this is hardly the case in practice.

8 Tibet, Hainan and Chongqing are excluded due to missing data. In the cases of Hainan and Chongqing, this is because these are new provinces, created recently by splitting away from Sichuan and Guangdong, respectively. For the same reason, we are unable to use data on Sichuan before the forming of Chongqing as a separate entity. Finally, we drop Tibet as almost no data is available on this province.

9 We used the following publications: 'Comprehensive Statistical Data and Materials 50 years of New China', China Labour Statistical Yearbook and provincial statistical books.

${ }^{10}$ The test results are available upon request.
} 
Table 3

Average provincial real GDP and growth rate, West.

\begin{tabular}{|c|c|c|c|c|c|}
\hline Provinces & & 1955-1965 & 1966-1977 & 1978-1991 & 1992-2011 \\
\hline \multirow[t]{2}{*}{ Guangxi } & GDP & 23.48 & 43.24 & 112.73 & 681.26 \\
\hline & growth & $5.36 \%$ & $6.61 \%$ & $7.84 \%$ & 11.93 \\
\hline \multirow[t]{2}{*}{ Sichuan } & GDP & - & - & 223.28 & 1236.55 \\
\hline & growth & - & - & $.85 \%$ & $.89 \%$ \\
\hline \multirow[t]{2}{*}{ Guizhou } & GDP & 14.89 & 18.91 & 61.93 & 292.73 \\
\hline & growth & $3.27 \%$ & $3.86 \%$ & $10.19 \%$ & $10.19 \%$ \\
\hline \multirow[t]{2}{*}{ Yunnan } & GDP & 21.93 & 35.26 & 104.66 & 539.47 \\
\hline & growth & $4.81 \%$ & $4.11 \%$ & $10.33 \%$ & $10.15 \%$ \\
\hline \multirow[t]{2}{*}{ Shaanxi } & GDP & 24.81 & 46.63 & 137.51 & 763.34 \\
\hline & growth & $5.12 \%$ & $6.19 \%$ & $9.48 \%$ & $11.26 \%$ \\
\hline \multirow[t]{2}{*}{ Gansu } & GDP & 19.26 & 37.21 & 101.80 & 540.26 \\
\hline & growth & $3.76 \%$ & $6.84 \%$ & $8.44 \%$ & $10.45 \%$ \\
\hline \multirow[t]{2}{*}{ Ningxia } & GDP & 4.12 & 10.35 & 30.60 & 154.32 \\
\hline & growth & $8.61 \%$ & $8.44 \%$ & $8.89 \%$ & $10.57 \%$ \\
\hline \multirow[t]{2}{*}{ Qinghai } & GDP & 4.41 & 8.31 & 20.88 & 94.56 \\
\hline & growth & $7.83 \%$ & $7.19 \%$ & $6.93 \%$ & $10.72 \%$ \\
\hline \multirow[t]{2}{*}{ Xinjiang } & GDP & 16.92 & 24.46 & 77.54 & 428.61 \\
\hline & growth & $8.09 \%$ & $3.11 \%$ & $10.99 \%$ & $9.88 \%$ \\
\hline
\end{tabular}

GDP is average provincial GDP over the period in 100 million Yuan.

Sources: 'Comprehensive Statistical Data and Materials 50 years of New China', China Labour Statistical Yearbook and provincial statistical books.

is motivated by the standard AS-AD analytical framework. Supply shocks, which are associated with shifts of the long-run aggregate supply, lead to permanent changes in both real output and prices. Demand shocks have also short-term effects on both output and prices. However, since in the long-run the aggregate supply curve is vertical, demand shocks do not have any long-term effect on the level of output and become fully absorbed by price-level adjustments.

Table 4

Weighted-average correlation of supply shocks by province.

\begin{tabular}{|c|c|c|c|c|c|}
\hline Region & Province name & 1955-1965 & 1966-1977 & 1978-1991 & 1992-2011 \\
\hline \multirow[t]{10}{*}{ East } & Beijing & 0.61 & 0.56 & 0.42 & 0.28 \\
\hline & Tianjin & 0.78 & 0.38 & 0.44 & 0.23 \\
\hline & Shanghai & 0.68 & 0.35 & 0.50 & 0.34 \\
\hline & Liaoning & 0.78 & 0.32 & 0.41 & -0.29 \\
\hline & Shandong & 0.63 & 0.39 & 0.47 & 0.27 \\
\hline & Jiangsu & 0.39 & 0.54 & 0.38 & 0.27 \\
\hline & Zhejiang & 0.69 & 0.11 & 0.54 & 0.37 \\
\hline & Fujian & 0.70 & 0.36 & 0.49 & 0.38 \\
\hline & Guangdong & 0.66 & 0.35 & 0.38 & 0.41 \\
\hline & Median East & 0.68 & 0.36 & 0.44 & 0.28 \\
\hline \multirow[t]{11}{*}{ Central } & Hebei & 0.71 & 0.44 & 0.51 & 0.30 \\
\hline & Shanxi & 0.78 & 0.51 & 0.25 & 0.10 \\
\hline & Inner-Mongolia & 0.64 & 0.49 & 0.23 & 0.08 \\
\hline & Jilin & 0.74 & 0.50 & 0.35 & 0.29 \\
\hline & Heilongjiang & 0.78 & 0.41 & 0.38 & -0.04 \\
\hline & Anhui & 0.47 & -0.08 & -0.21 & 0.06 \\
\hline & Jiangxi & 0.43 & 0.46 & 0.39 & 0.35 \\
\hline & Henan & 0.72 & 0.36 & 0.20 & -0.09 \\
\hline & Hunan & 0.78 & 0.53 & 0.38 & 0.34 \\
\hline & Hubei & 0.72 & 0.50 & 0.37 & 0.24 \\
\hline & Median Center & 0.72 & 0.48 & 0.36 & 0.17 \\
\hline \multirow[t]{11}{*}{ West } & Guangxi & 0.76 & 0.25 & 0.40 & 0.44 \\
\hline & Sichuan & - & - & 0.47 & 0.27 \\
\hline & Guizhou & 0.82 & 0.36 & 0.29 & 0.02 \\
\hline & Yunnan & 0.62 & 0.40 & 0.39 & 0.24 \\
\hline & Shaanxi & 0.78 & 0.38 & 0.43 & -0.06 \\
\hline & Gansu & 0.61 & 0.20 & 0.35 & 0.22 \\
\hline & Ningxia & 0.58 & 0.32 & 0.31 & -0.17 \\
\hline & Qinghai & 0.70 & 0.24 & 0.39 & 0.16 \\
\hline & Xinjiang & 0.59 & 0.52 & 0.28 & 0.27 \\
\hline & Median West & 0.70 & 0.36 & 0.39 & 0.22 \\
\hline & Median China & 0.70 & 0.39 & 0.39 & 0.27 \\
\hline
\end{tabular}

Source: Own calculations (see text for details). 
Table 5

Weighted-average correlation of demand shocks by province.

\begin{tabular}{|c|c|c|c|c|c|}
\hline Region & Province name & 1955-1965 & 1966-1977 & 1978-1991 & 1992-2011 \\
\hline \multirow[t]{10}{*}{ East } & Beijing & 0.02 & 0.04 & 0.44 & 0.66 \\
\hline & Tianjin & 0.25 & 0.20 & 0.49 & 0.76 \\
\hline & Shanghai & 0.20 & 0.15 & 0.34 & 0.75 \\
\hline & Liaoning & -0.18 & 0.18 & 0.19 & 0.59 \\
\hline & Shandong & 0.24 & 0.08 & 0.20 & 0.63 \\
\hline & Jiangsu & -0.07 & 0.18 & 0.38 & 0.80 \\
\hline & Zhejiang & 0.28 & 0.07 & 0.42 & 0.78 \\
\hline & Fujian & 0.19 & -0.13 & 0.48 & 0.73 \\
\hline & Guangdong & 0.20 & 0.09 & 0.37 & 0.73 \\
\hline & Median East & 0.20 & 0.09 & 0.38 & 0.73 \\
\hline \multirow[t]{11}{*}{ Central } & Hebei & 0.18 & 0.08 & 0.50 & 0.77 \\
\hline & Shanxi & 0.06 & 0.20 & 0.40 & 0.73 \\
\hline & Inner-Mongolia & 0.07 & -0.02 & 0.44 & 0.77 \\
\hline & Jilin & 0.20 & 0.02 & 0.11 & 0.66 \\
\hline & Heilongjiang & 0.13 & 0.29 & 0.23 & 0.81 \\
\hline & Anhui & -0.18 & 0.28 & 0.40 & 0.70 \\
\hline & Jiangxi & 0.22 & 0.15 & 0.46 & 0.74 \\
\hline & Henan & -0.05 & 0.28 & 0.38 & 0.77 \\
\hline & Hunan & 0.22 & -0.18 & 0.38 & 0.81 \\
\hline & Hubei & 0.10 & 0.10 & 0.39 & 0.78 \\
\hline & Median Center & 0.12 & 0.13 & 0.40 & 0.77 \\
\hline \multirow[t]{11}{*}{ West } & Guangxi & 0.15 & 0.01 & 0.53 & 0.76 \\
\hline & Sichuan & - & - & 0.32 & 0.73 \\
\hline & Guizhou & 0.25 & 0.16 & 0.53 & 0.76 \\
\hline & Yunnan & 0.20 & -0.19 & 0.30 & 0.69 \\
\hline & Shaanxi & 0.16 & 0.23 & 0.24 & 0.74 \\
\hline & Gansu & 0.18 & -0.22 & 0.21 & 0.51 \\
\hline & Ningxia & 0.19 & -0.04 & 0.48 & 0.77 \\
\hline & Qinghai & 0.15 & -0.11 & 0.40 & 0.77 \\
\hline & Xinjiang & -0.06 & -0.15 & 0.39 & 0.70 \\
\hline & Median West & 0.18 & -0.04 & 0.39 & 0.74 \\
\hline & Median China & 0.18 & 0.09 & 0.39 & 0.74 \\
\hline
\end{tabular}

Source: Own calculations (see text for details).

Following Blanchard and Quah (1989) and Bayoumi and Eichengreen (1993), we estimate, for each province, the following SVAR model involving real output growth and price-level growth:

$$
\mathbf{Y}_{t}=\mathbf{B}_{1} \mathbf{Y}_{t-1}+\mathbf{B}_{2} \mathbf{Y}_{t-1}+\ldots+\mathbf{B}_{k} \mathbf{Y}_{t-k}+\mathbf{e}_{t}
$$

where $\mathbf{B}$ are matrices of estimated coefficients with $k$ lags, and $\mathbf{e}=\left(e_{t}^{y}, e_{t}^{p}\right)^{\prime}$ are i. i. d. disturbances. This model can be represented by the following infinite vector moving average (VMA) process

$$
\mathbf{Y}_{t}=\mathbf{e}_{t}+\mathbf{B}_{1} \mathbf{e}_{t-1}+\ldots=\sum_{i=}^{\infty} \mathbf{C}_{i} L^{i} \mathbf{e}_{t}
$$

The VAR disturbances are assumed to be serially uncorrelated, but they may and usually are contemporaneously correlated. Therefore, we decompose them into structural shocks which are orthogonal and which fulfill the theoretical properties derived from the AS-AD model, ${ }^{11}$

$$
\mathbf{Y}_{t}=\mathbf{A}_{0} \boldsymbol{\varepsilon}_{t}+\mathbf{A}_{1} \boldsymbol{\varepsilon}_{t-1}+\ldots=\sum_{i=}^{\infty} \mathbf{A}_{i} L^{i} \boldsymbol{\varepsilon}_{t}
$$

where $\varepsilon=\left(\varepsilon^{D}, \varepsilon^{S}\right)^{\prime}$ is a vector of demand and supply shocks, respectively. This implies that unexplainable components of output growth and inflation are driven by supply and demand shocks. The vector of unobservable structural disturbances, $\varepsilon$, can be obtained from Eqs. (2) and (3), which gives $\mathbf{e}_{t}=\mathbf{A}_{0} \varepsilon_{t}$. Correspondingly, the variance-covariance matrix of VAR residuals can be presented as $\boldsymbol{\Sigma}_{e}=\mathbf{A}_{0} \boldsymbol{\Sigma}_{\varepsilon} \mathbf{A}_{0}^{-1}$. Thus, the structural shocks can be derived from the variance-covariance matrix of residuals, $\mathbf{e}$, and the normalization of variance-covariance matrix of structural shocks, $\Sigma_{\varepsilon}$, to the identity matrix. Moreover, we impose the restriction that demand shocks have no long-term impact on the level of output, $\sum_{i=0}^{\infty} c_{i, 11} \varepsilon_{t-i}^{D}=0$.

\footnotetext{
11 Stazka (2006), among others, describes the Blanchard-Quah decomposition in more detail.
} 
$1955-1965$
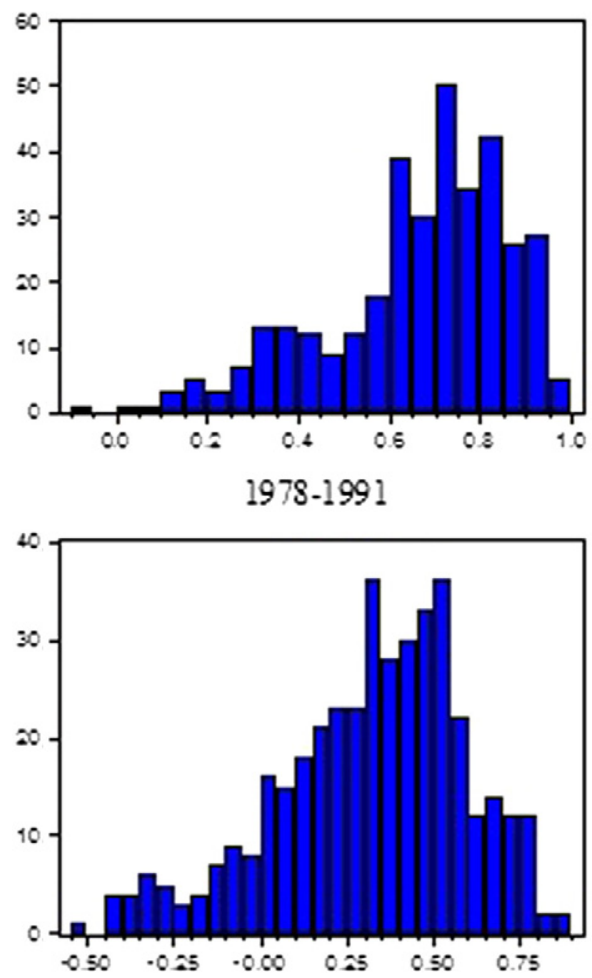

$1966-1977$
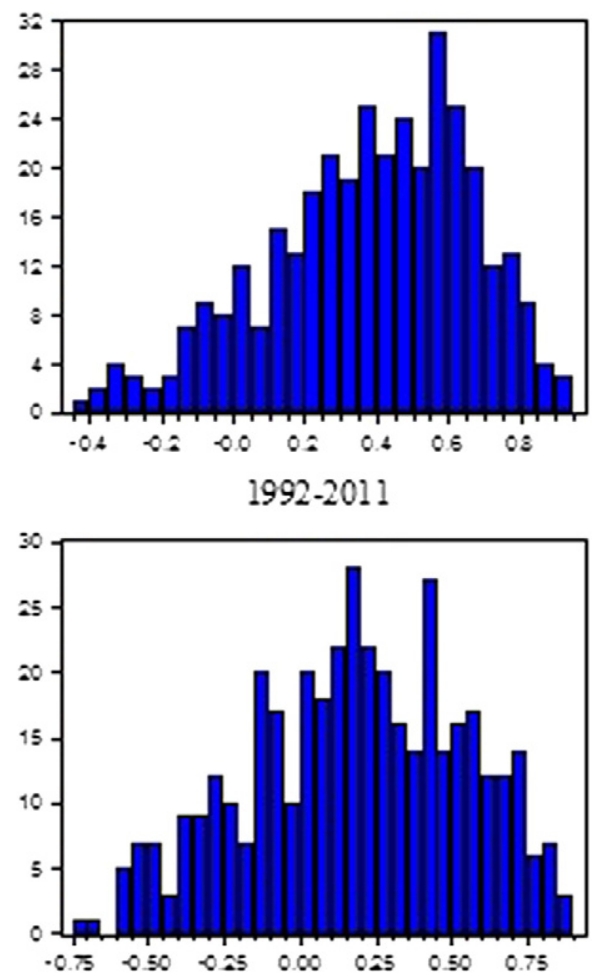

Fig. 1. Interprovince correlation of supply shocks. Notes: The horizontal axis shows correlation coefficients while the vertical axis reports the number of observations (province pairs) with that correlation. Source: Own calculations (see text for details).

\subsection{Correlations of supply and demand shocks}

Having estimated the demand and supply shocks affecting the individual provinces, we calculate $\rho_{i j \tau}^{S}$ and $\rho_{i j \tau}^{D}$, the correlation of supply and demand shocks between any two provinces $i$ and $j$ during sub-period (2.925). If the correlation of shocks is positive, the shocks are considered to be symmetric and if it is negative, they are asymmetric. Tables 4 and 5 give the weighted-average (with GDP used as weights) correlations of supply and demand shocks for each province and for each sub-period. The tables also report the median figures for each region and sub-period and for China as a whole. ${ }^{12}$ Fig. 1 depicts the distribution of bilateral cross correlations of supply shocks for the four sub-periods while Fig. 2 provides the same information for demand shocks. It is clear that the nature of shocks is changing over time. However, the change is not the same for the two kinds of shocks. In particular, the correlations of supply shocks display a lower degree of business-cycle synchronization during the more recent periods. The Chinawide median falls considerably, from 0.70 to 0.27 during the period covered by our analysis. In contrast, the development of demand shocks suggests a greater degree of synchronization in the later periods. The China-wide median correlation more than quadruples, from 0.18 to 0.74 . Rather remarkably, the China-wide pattern is mirrored also in the change of the regional medians, both for supply and demand shocks, suggesting that this divergent development of supply and demand shock is not limited only to a subset of provinces. There are some outliers, such as the deeply-negative correlation of supply shocks for Liaoning in the latest sub-period. ${ }^{13}$ Hence, depending on which type of shocks we look at, Chinese provinces either appear to have become more closely integrated or have grown increasingly apart since the reforms have been implemented.

The focus on the symmetry of shocks is at the core of the optimum currency area (OCA) theory (Mundell, 1961). If shocks are sufficiently symmetric, the argument goes, the countries or regions sharing the same currency will have little need for independent monetary policy. With asymmetric shocks, policy preferences can diverge: a region hit by a negative shock would prefer expansionary monetary policy while that affected by a positive shock would be in favor of a monetary tightening. The OCA theory, however, considers only the overall symmetry of shocks, without dwelling on the distinction between demand and supply shocks. Therefore, it

\footnotetext{
12 The provincial figures forming the regional medians are depicted by italics in the tables. Note that the Central region has an even number of provinces so that two of them were used to compute the median value for that region; both are in italics in the table while their average is reported as the median.

13 There are several factors which can explain the result for this province. First, Liaoning used to be one of the most heavily industrialized areas of China, with its economy following the Soviet model with an emphasis on heavy industry. As such, it was heavily reliant on imports of resources at below-market prices from the other provinces. The imports of cheap resources largely ceased during the reform period, which resulted in decline of Liaoning's economy at a time when other provinces were doing well. Second, Liaoning is at the border with North Korea and the famine in that country (and the ensuing refugee influx) could have influenced also the economy of the Northeast region of China.
} 
$1955-1965$
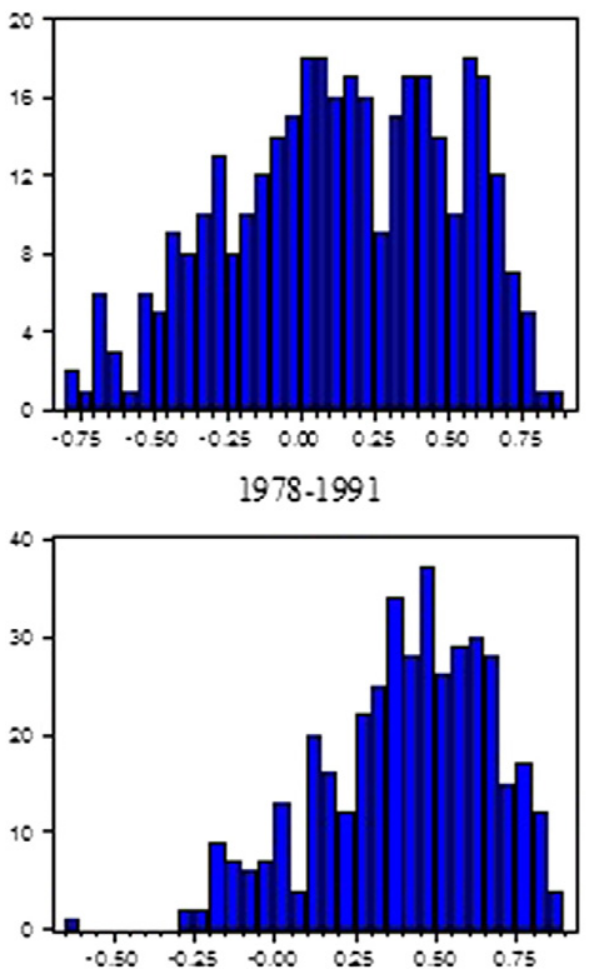

$1966-1977$
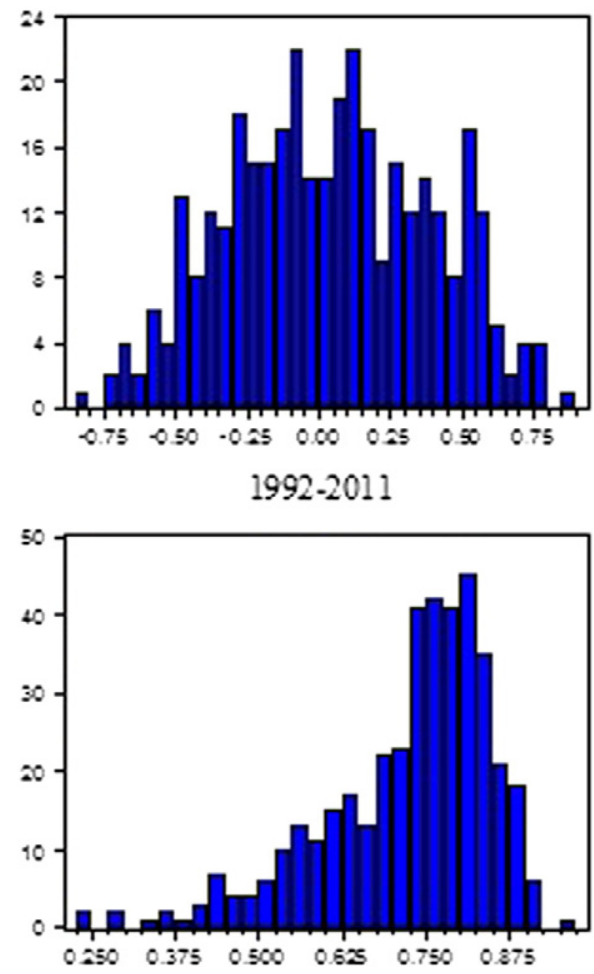

Fig. 2. Interprovince correlation of demand shocks. Notes: The horizontal axis shows correlation coefficients while the vertical axis reports the number of observations (province pairs) with that correlation. Source: Own calculations (see text for details).

Table 6

Determinants of interprovince correlation of supply shocks, Maoist period.

\begin{tabular}{|c|c|c|c|c|}
\hline & \multicolumn{2}{|l|}{ 1955-1965 } & \multicolumn{2}{|c|}{$1966-1977$} \\
\hline & 0 & $z$ & 0 & $z$ \\
\hline Common-border dummy & $\begin{array}{l}0.044 \\
(0.042)\end{array}$ & $\begin{array}{l}0.077 \\
(0.089)\end{array}$ & $\begin{array}{l}0.009 \\
(0.063)\end{array}$ & $\begin{array}{l}0.017 \\
(0.082)\end{array}$ \\
\hline Coast dummy & $\begin{array}{l}-0.107^{* *} \\
(0.047)\end{array}$ & $\begin{array}{l}-0.228^{* * *} \\
(0.092)\end{array}$ & $\begin{array}{l}-0.060 \\
(0.064)\end{array}$ & $\begin{array}{l}-0.094 \\
(0.082)\end{array}$ \\
\hline Same-region dummy & $\begin{array}{l}0.044 \\
(0.032)\end{array}$ & $\begin{array}{l}0.073 \\
(0.066)\end{array}$ & $\begin{array}{l}0.067 \\
(0.050)\end{array}$ & $\begin{array}{l}0.109 \\
(0.066)\end{array}$ \\
\hline Coast-interior dummy & $\begin{array}{l}-0.030 \\
(0.067)\end{array}$ & $\begin{array}{l}-0.087 \\
(0.130)\end{array}$ & $\begin{array}{l}0.054 \\
(0.096)\end{array}$ & $\begin{array}{l}0.063 \\
(0.122)\end{array}$ \\
\hline Railway (freight) distance [in 1000s km] & $\begin{array}{l}0.020 \\
(0.011)\end{array}$ & $\begin{array}{l}0.026 \\
(0.022)\end{array}$ & $\begin{array}{l}0.008 \\
(0.019)\end{array}$ & $\begin{array}{l}0.016 \\
(0.023)\end{array}$ \\
\hline Economic size $\left[\log Y_{i}+\log Y_{j}\right]$ & $\begin{array}{l}0.013 \\
(0.039)\end{array}$ & $\begin{array}{l}0.025 \\
(0.074)\end{array}$ & $\begin{array}{l}0.001 \\
(0.048)\end{array}$ & $\begin{array}{l}0.023 \\
(0.061)\end{array}$ \\
\hline Dissimilarity of physical capital & $\begin{array}{l}-0.529^{* *} \\
(0.244)\end{array}$ & $\begin{array}{l}-1.024^{* *} \\
(0.450)\end{array}$ & $\begin{array}{l}-0.130 \\
(0.341)\end{array}$ & $\begin{array}{l}-0.030 \\
(0.423)\end{array}$ \\
\hline Dissimilarity of human capital & $\begin{array}{l}0.025^{* * *} \\
(0.006)\end{array}$ & $\begin{array}{l}0.041^{* * *} \\
(0.011)\end{array}$ & $\begin{array}{l}0.024^{* *} \\
(0.012)\end{array}$ & $\begin{array}{l}0.022 \\
(0.015)\end{array}$ \\
\hline Dissimilarity of inflation & $\begin{array}{l}-0.001 \\
(0.001)\end{array}$ & $\begin{array}{l}-0.002 \\
(0.002)\end{array}$ & $\begin{array}{l}-0.003 \\
(0.003)\end{array}$ & $\begin{array}{l}-0.003 \\
(0.003)\end{array}$ \\
\hline Standard deviation of fiscal deficit differentials & $\begin{array}{l}0.496^{* *} \\
(0.228)\end{array}$ & $\begin{array}{l}1.080^{* *} \\
(0.466)\end{array}$ & $\begin{array}{l}-0.741 \\
(0.548)\end{array}$ & $\begin{array}{l}-1.298 \\
(0.705)\end{array}$ \\
\hline Constant & $\begin{array}{l}0.586^{* *} \\
(0.136)\end{array}$ & $\begin{array}{l}0.780^{* * *} \\
(0.256)\end{array}$ & $\begin{array}{l}0.400^{* *} \\
(0.201)\end{array}$ & $\begin{array}{l}0.384 \\
(0.254)\end{array}$ \\
\hline Observations & 325 & 325 & 324 & 324 \\
\hline$R^{2}$ & 0.05 & 0.05 & 0.02 & 0.03 \\
\hline
\end{tabular}

Robust standard errors in parentheses. Significance: ${ }^{* * *} 1 \%,{ }^{* *} 5 \%,{ }^{*} 10 \%$. Dependent variable: original correlations (o) and Fisher $z$-transformations (z). The commonborder and same-region dummies denote provinces that share a border and belong to the same region (East, Central or West), respectively. The coast and coast-interior dummies denote provinces that are both on the coast and where one is on the coast and the other in the interior, respectively. Distance is railway freight distance in kilometers. Economic size is the sum of the provincial GDPs in logs. Dissimilarity index of variable $X$ is defined as $\frac{1}{K} \sum_{n=1}^{K}\left|X_{i n}-X_{j n}\right|$, where $K$ counts the sectors/periods and $X$ stands for physical capital, human capital, inflation, trade, FDI, or output structure. Source: Own calculations. 
Table 7

Determinants of interprovince correlation of supply shocks, reform period.

\begin{tabular}{|c|c|c|c|c|}
\hline & \multicolumn{2}{|l|}{ 1978-1991 } & \multicolumn{2}{|l|}{ 1992-2011 } \\
\hline & 0 & $z$ & 0 & $z$ \\
\hline Common-border dummy & $\begin{array}{l}0.031 \\
(0.051)\end{array}$ & $\begin{array}{l}0.046 \\
(0.062)\end{array}$ & $\begin{array}{l}0.202^{* * *} \\
(0.057)\end{array}$ & $\begin{array}{l}0.241^{* * *} \\
(0.068)\end{array}$ \\
\hline Coast dummy & $\begin{array}{l}0.178^{* * *} \\
(0.053)\end{array}$ & $\begin{array}{l}0.224^{* * *} \\
(0.068)\end{array}$ & $\begin{array}{l}0.235^{* * *} \\
(0.080)\end{array}$ & $\begin{array}{l}0.306^{* * *} \\
(0.099)\end{array}$ \\
\hline Same-region dummy & $\begin{array}{l}-0.021 \\
(0.041)\end{array}$ & $\begin{array}{l}-0.021 \\
(0.048)\end{array}$ & $\begin{array}{l}-0.005 \\
(0.045)\end{array}$ & $\begin{array}{l}-0.011 \\
(0.053)\end{array}$ \\
\hline Coast-interior dummy & $\begin{array}{l}0.017 \\
(0.088)\end{array}$ & $\begin{array}{l}-0.018 \\
(0.110)\end{array}$ & $\begin{array}{l}-0.202 \\
(0.112)\end{array}$ & $\begin{array}{l}-0.249 \\
(0.134)\end{array}$ \\
\hline Railway (freight) distance [in 1000s km] & $\begin{array}{l}-0.023 \\
(0.019)\end{array}$ & $\begin{array}{l}-0.033 \\
(0.022)\end{array}$ & $\begin{array}{l}0.021 \\
(0.025)\end{array}$ & $\begin{array}{l}0.027 \\
(0.029)\end{array}$ \\
\hline Economic size $\left[\log Y_{i}+\log Y_{j}\right]$ & $\begin{array}{l}0.023 \\
(0.035)\end{array}$ & $\begin{array}{l}0.011 \\
(0.044)\end{array}$ & $\begin{array}{l}-0.037 \\
(0.050)\end{array}$ & $\begin{array}{l}-0.045 \\
(0.059)\end{array}$ \\
\hline Dissimilarity of physical capital & $\begin{array}{l}-1.693^{* * *} \\
(0.367)\end{array}$ & $\begin{array}{l}-2.071^{* * *} \\
(0.441)\end{array}$ & $\begin{array}{l}-1.191^{* * *} \\
(0.393)\end{array}$ & $\begin{array}{l}-1.380^{* * *} \\
(0.452)\end{array}$ \\
\hline Dissimilarity of human capital & $\begin{array}{l}5.501^{* *} \\
(2.419)\end{array}$ & $\begin{array}{l}6.002^{* *} \\
(2.925)\end{array}$ & $\begin{array}{l}-8.027^{* *} \\
(3.863)\end{array}$ & $\begin{array}{l}-8.739^{* *} \\
(4.447)\end{array}$ \\
\hline Dissimilarity of inflation & $\begin{array}{l}0.016 \\
(0.012)\end{array}$ & $\begin{array}{l}0.019 \\
(0.015)\end{array}$ & $\begin{array}{l}0.063^{* *} \\
(0.031)\end{array}$ & $\begin{array}{l}0.074^{* *} \\
(0.036)\end{array}$ \\
\hline Standard deviation of fiscal deficit differentials & $\begin{array}{l}1.139^{* *} \\
(0.548)\end{array}$ & $\begin{array}{l}1.351^{* *} \\
(0.662)\end{array}$ & $\begin{array}{l}0.593 \\
(0.909)\end{array}$ & $\begin{array}{l}0.453 \\
(1.058)\end{array}$ \\
\hline Dissimilarity of trade & $\begin{array}{l}0.095 \\
(0.165)\end{array}$ & $\begin{array}{l}0.089 \\
(0.197)\end{array}$ & $\begin{array}{l}0.069 \\
(0.067)\end{array}$ & $\begin{array}{l}0.097 \\
(0.078)\end{array}$ \\
\hline Dissimilarity of FDI & $\begin{array}{l}-4.656 \\
(3.788)\end{array}$ & $\begin{array}{l}-5.242 \\
(4.477)\end{array}$ & $\begin{array}{l}-0.088 \\
(0.107)\end{array}$ & $\begin{array}{l}-0.122 \\
(0.117)\end{array}$ \\
\hline Dissimilarity of output structure & $\begin{array}{l}-0.163 \\
(0.131)\end{array}$ & $\begin{array}{l}-0.157 \\
(0.153)\end{array}$ & $\begin{array}{l}0.420 \\
(0.270)\end{array}$ & $\begin{array}{l}0.469 \\
(0.320)\end{array}$ \\
\hline Constant & $\begin{array}{l}0.277 \\
(0.171)\end{array}$ & $\begin{array}{l}0.393 \\
(0.209)\end{array}$ & $\begin{array}{l}0.310 \\
(0.326)\end{array}$ & $\begin{array}{l}0.369 \\
(0.381)\end{array}$ \\
\hline Observations & 378 & 378 & 378 & 378 \\
\hline$R^{2}$ & 0.13 & 0.13 & 0.11 & 0.12 \\
\hline
\end{tabular}

Robust standard errors in parentheses. Significance: ${ }^{* *} 1 \%,{ }^{* *} 5 \%,{ }^{*} 10 \%$. Dependent variable: original correlations (o) and Fisher $z$-transformations (z). The commonborder and same-region dummies denote provinces that share a border and belong to the same region (East, Central or West), respectively. The coast and coast-interior dummies denote provinces that are both on the coast and where one is on the coast and the other in the interior, respectively. Distance is railway freight distance in kilometers. Economic size is the sum of the provincial GDPs in logs. Dissimilarity index of variable $X$ is defined as $\frac{1}{K} \sum_{n=1}^{K}\left|X_{i n}-X_{j n}\right|$, where $K$ counts the sectors/periods and $X$ stands for physical capital, human capital, inflation, trade, FDI, or output structure. Source: Own calculations.

gives us little guidance as to how to evaluate cases such as China's where falling correlation of supply shocks seems counter-balanced by increasing symmetry of demand shocks.

Fidrmuc (2013), in contrast, presents a model of fiscal integration in which the difference between permanent and temporary output shocks plays an important role (recall that supply shocks affect output permanently while demand shocks only have a temporary effect). He argues that symmetry of permanent shocks is more important for the stability of integration than symmetry of temporary shocks: both kinds of shocks give rise to divergent policy preferences but the impact of temporary shocks is (by definition) short lived while permanent shocks can fundamentally undermine the stability of integration. In this context, the fact that China is experiencing falling correlation of supply (permanent) shocks may come across as worrying, despite the movement in the opposite direction by the correlation of demand (temporary) shocks.

\section{Determinants of business cycle co-movement in China}

\subsection{Methodology}

So far, we have explored the changing nature of business-cycle synchronization during the last five decades of China's history. In this section, we investigate the determinants of business cycle co-movements and, thereby, shed some light on the factors behind the different developments of supply and demand shocks discussed in the preceding section. Our approach is motivated by Artis and Okubo (2010 and 2011) who were the first to apply this kind of framework to identify the determinants of business-cycle similarity in the inter-regional setting (the UK and Japan, respectively). While Artis and Okubo measured business-cycle synchronization using HP filtered GDP correlations, we use the correlations of supply and demand shocks, discussed in the preceding section, as the dependent variables. As Artis and Okubo, we analyze the correlation coefficients using a form of a gravity model, regressing them on the distance between the two provinces and a number of provincial variables.

The correlations of supply and demand shocks, $\rho_{i j \tau}^{S}$ and $\rho_{i j \tau}^{D}$, estimated for provinces $i$ and $j$ during sub-period $\tau$, are defined between -1 and +1 whereas OLS assumes that the dependent variables are unbounded. Therefore, besides using the original 
Table 8

Determinants of interprovince correlation of demand shocks, Maoist period.

\begin{tabular}{|c|c|c|c|c|}
\hline & \multicolumn{2}{|l|}{$1955-1965$} & \multicolumn{2}{|l|}{$1966-1977$} \\
\hline & 0 & $z$ & 0 & $z$ \\
\hline Common-border dummy & $\begin{array}{l}0.012 \\
(0.080)\end{array}$ & $\begin{array}{l}0.010 \\
(0.091)\end{array}$ & $\begin{array}{l}0.064 \\
(0.066)\end{array}$ & $\begin{array}{l}0.065 \\
(0.075)\end{array}$ \\
\hline Coast dummy & $\begin{array}{l}0.110 \\
(0.095)\end{array}$ & $\begin{array}{l}0.133 \\
(0.112)\end{array}$ & $\begin{array}{l}-0.062 \\
(0.075)\end{array}$ & $\begin{array}{l}-0.082 \\
(0.083)\end{array}$ \\
\hline Same-region dummy & $\begin{array}{l}-0.044 \\
(0.061)\end{array}$ & $\begin{array}{l}-0.052 \\
(0.070)\end{array}$ & $\begin{array}{l}0.007 \\
(0.058)\end{array}$ & $\begin{array}{l}0.014 \\
(0.068)\end{array}$ \\
\hline Coast-interior dummy & $\begin{array}{l}-0.018 \\
(0.135)\end{array}$ & $\begin{array}{l}-0.031 \\
(0.158)\end{array}$ & $\begin{array}{l}-0.185^{* *} \\
(0.087)\end{array}$ & $\begin{array}{l}-0.205^{* *} \\
(0.094)\end{array}$ \\
\hline Railway (freight) distance [in 1000s km] & $\begin{array}{l}0.003 \\
(0.026)\end{array}$ & $\begin{array}{l}0.004 \\
(0.030)\end{array}$ & $\begin{array}{l}-0.092^{* *} \\
(0.023)\end{array}$ & $\begin{array}{l}-0.100^{*} \\
(0.028)\end{array}$ \\
\hline Economic size $\left[\log Y_{i}+\log Y_{j}\right]$ & $\begin{array}{l}-0.135^{* *} \\
(0.061)\end{array}$ & $\begin{array}{l}-0.153^{* *} \\
(0.070)\end{array}$ & $\begin{array}{l}0.027 \\
(0.066)\end{array}$ & $\begin{array}{l}0.031 \\
(0.078)\end{array}$ \\
\hline Dissimilarity of physical capital & $\begin{array}{l}-0.569 \\
(0.442)\end{array}$ & $\begin{array}{l}-0.684 \\
(0.514)\end{array}$ & $\begin{array}{l}-0.667 \\
(0.429)\end{array}$ & $\begin{array}{l}-0.743 \\
(0.507)\end{array}$ \\
\hline Dissimilarity of human capital & $\begin{array}{l}-0.016 \\
(0.025)\end{array}$ & $\begin{array}{l}-0.019 \\
(0.026)\end{array}$ & $\begin{array}{l}0.057 \\
(0.034)\end{array}$ & $\begin{array}{l}0.062 \\
(0.039)\end{array}$ \\
\hline Dissimilarity of inflation & $\begin{array}{l}-0.003 \\
(0.002)\end{array}$ & $\begin{array}{l}-0.004 \\
(0.003)\end{array}$ & $\begin{array}{l}-0.003 \\
(0.003)\end{array}$ & $\begin{array}{l}-0.003 \\
(0.003)\end{array}$ \\
\hline Standard deviation of fiscal deficit differentials & $\begin{array}{l}0.368 \\
(0.349)\end{array}$ & $\begin{array}{l}0.403 \\
(0.404)\end{array}$ & $\begin{array}{l}-0.087 \\
(0.656)\end{array}$ & $\begin{array}{l}-0.126 \\
(0.739)\end{array}$ \\
\hline Constant & $\begin{array}{l}0.568^{* * *} \\
(0.218)\end{array}$ & $\begin{array}{l}0.652^{* * *} \\
(0.249)\end{array}$ & $\begin{array}{l}0.194 \\
(0.273)\end{array}$ & $\begin{array}{l}0.215 \\
(0.328)\end{array}$ \\
\hline Observations & 325 & 325 & 324 & 324 \\
\hline$R^{2}$ & 0.02 & 0.02 & 0.13 & 0.12 \\
\hline
\end{tabular}

Robust standard errors in parentheses. Significance: *** $1 \%,{ }^{* *} 5 \%,{ }^{*} 10 \%$. Dependent variable: original correlations (o) and Fisher $z$-transformations (z). The commonborder and same-region dummies denote provinces that share a border and belong to the same region (East, Central or West), respectively. The coast and coast-interior dummies denote provinces that are both on the coast and where one is on the coast and the other in the interior, respectively. Distance is railway freight distance in kilometers. Economic size is the sum of the provincial GDPs in logs. Dissimilarity index of variable $X$ is defined as $\frac{1}{K} \sum_{n=1}^{K}\left|X_{i n}-X_{j n}\right|$, where $K$ counts the sectors/periods and $X$ stands for physical capital, human capital, inflation, trade, FDI, or output structure. Source: Own calculations.

correlation coefficients, we follow Artis and Okubo's approach by considering also the Fisher- $z$ transformation of these coefficients. These are not bounded from above or below:

$$
z=\frac{1}{2} \log \left(\frac{1+\rho_{i j \tau}}{1-\rho_{i j \tau}}\right)
$$

To explain the degree of shock synchronization between pairs of provinces, we introduce a wide range of explanatory variables. As we highlight in the discussion of the determinants of business-cycle co-movements, bilateral trade intensity is likely to increase the synchronization of business cycles between provinces. Data on internal trade flows in any country, however, are notoriously difficult to obtain: unlike foreign trade, internal trade flows attract little official scrutiny and may be difficult to measure (for instance, intrafirm deliveries crossing provincial borders are unlikely to be included in official statistics on interprovincial trade, even if such statistics are collected). There is abundant evidence in the existing literature that the gravity model explains bilateral trade very well (see, for example, Baldwin and Taglioni (2006); de Haan et al. (2008b); Frankel and Rose (1998)). We therefore include the following commonly used gravity variables: dummy for a common border (equal to (0.031) for adjacent provinces), same-region dummy (equal to $0.074^{* *}$ when two provinces belong to the same region: East, Center and West), coast and interior-coast dummies ${ }^{14}$ (equal to (0.036) when both provinces are located in the coastal region and when one province is on the coast while the other lies in the interior, respectively), bilateral distance (the shortest distance for freight transportation by railway in kilometers), and economic size (measured as the sum of the two provincial GDPs, $\log Y_{i}+\log Y_{j}$ ).

Regions specializing in producing similar goods are likely to be exposed to similar shocks. There is, however, no standard measure of similarity in the production structure. Following Clark and van Wincoop (2001), Imbs (2004) and Poncet and Barthèlemy (2008), we compute Krugman's (1991) absolute value index. Let $S_{n i}$ and $S_{n j}$ denote the GDP shares for industry $n$ in provinces $i$ and $j$. Then, the dissimilarity of the two provinces' production structures is measured as

$$
\frac{1}{N} \sum_{n=1}^{N}\left|S_{n i}-S_{n j}\right|
$$

\footnotetext{
${ }^{14}$ These two dummies should reveal up whether business cycles are more closely synchronized among coast provinces (captured by the coast dummy), between coast and interior provinces (coast-interior dummy), or among interior provinces (omitted category).
} 
Table 9

Determinants of interprovince correlation of demand shocks, reform period.

\begin{tabular}{|c|c|c|c|c|}
\hline & \multicolumn{2}{|l|}{ 1978-1991 } & \multicolumn{2}{|l|}{ 1992-2011 } \\
\hline & 0 & $z$ & 0 & $z$ \\
\hline \multirow[t]{2}{*}{ Common-border dummy } & -0.039 & -0.040 & -0.013 & -0.033 \\
\hline & $(0.050)$ & $(0.063)$ & $(0.023)$ & $(0.050)$ \\
\hline \multirow[t]{2}{*}{ Coast dummy } & $0.152^{* * *}$ & $0.192^{* * * *}$ & -0.032 & -0.058 \\
\hline & $(0.059)$ & $(0.075)$ & $(0.031)$ & $(0.063)$ \\
\hline \multirow[t]{2}{*}{ Same-region dummy } & $-0.096^{* * *}$ & $-0.127^{* * *}$ & -0.010 & -0.011 \\
\hline & $(0.035)$ & $(0.043)$ & $(0.018)$ & $(0.039)$ \\
\hline \multirow[t]{2}{*}{ Coast-interior dummy } & 0.037 & 0.070 & -0.050 & -0.115 \\
\hline & $(0.096)$ & $(0.126)$ & $(0.033)$ & $(0.070)$ \\
\hline \multirow[t]{2}{*}{ Railway (freight) distance [in 1000s km] } & $-0.071^{* * *}$ & $-0.098^{* * *}$ & $-0.027^{* * *}$ & $-0.058^{* * *}$ \\
\hline & $(0.019)$ & $(0.023)$ & $(0.008)$ & $(0.017)$ \\
\hline \multirow[t]{2}{*}{ Economic size $\left[\log Y_{i}+\log Y_{j}\right]$} & $-0.159^{* * *}$ & $-0.200^{* * *}$ & -0.035 & -0.074 \\
\hline & $(0.037)$ & $(0.049)$ & $(0.017)$ & $(0.039)$ \\
\hline \multirow[t]{2}{*}{ Dissimilarity of physical capital } & 0.525 & 0.637 & 0.058 & 0.080 \\
\hline & $(0.382)$ & $(0.507)$ & $(0.133)$ & $(0.272)$ \\
\hline \multirow[t]{2}{*}{ Dissimilarity of human capital } & 0.774 & 2.157 & $-3.117^{* *}$ & $-6.436^{* *}$ \\
\hline & $(2.406)$ & $(3.033)$ & $(1.288)$ & $(2.655)$ \\
\hline \multirow[t]{2}{*}{ Dissimilarity of inflation } & $0.069^{* * *}$ & $0.092^{* * *}$ & $0.018^{* *}$ & 0.029 \\
\hline & $(0.010)$ & $(0.015)$ & $(0.009)$ & $(0.021)$ \\
\hline \multirow[t]{2}{*}{ Standard deviation of fiscal deficit differentials } & -0.315 & -0.353 & -0.260 & -0.305 \\
\hline & $(0.559)$ & $(0.694)$ & $(0.318)$ & $(0.675)$ \\
\hline \multirow[t]{2}{*}{ Dissimilarity of trade } & -0.168 & -0.176 & 0.010 & 0.012 \\
\hline & $(0.185)$ & $(0.241)$ & $(0.022)$ & $(0.044)$ \\
\hline \multirow[t]{2}{*}{ Dissimilarity of FDI } & -2.197 & -3.911 & -0.051 & -0.121 \\
\hline & $(3.817)$ & $(4.985)$ & $(0.058)$ & $(0.124)$ \\
\hline \multirow[t]{2}{*}{ Dissimilarity of output structure } & -0.088 & -0.145 & -0.079 & -0.261 \\
\hline & $(0.119)$ & $(0.150)$ & $(0.087)$ & $(0.209)$ \\
\hline \multirow[t]{2}{*}{ Constant } & $1.132^{* * *}$ & $1.383^{* * *}$ & $0.593^{* * *}$ & $1.607^{* * *}$ \\
\hline & $(0.176)$ & $(0.231)$ & $(0.153)$ & $(0.251)$ \\
\hline Observations & 378 & 378 & 378 & 378 \\
\hline$R^{2}$ & 0.16 & 0.17 & 0.07 & 0.07 \\
\hline
\end{tabular}

Robust standard errors in parentheses. Significance: ${ }^{* * *} 1 \%,{ }^{* *} 5 \%,{ }^{*} 10 \%$. Dependent variable: original correlations (o) and Fisher $z$-transformations (z). The commonborder and same-region dummies denote provinces that share a border and belong to the same region (East, Central or West), respectively. The coast and coast-interior dummies denote provinces that are both on the coast and where one is on the coast and the other in the interior, respectively. Distance is railway freight distance in kilometers. Economic size is the sum of the provincial GDPs in logs. Dissimilarity index of variable $X$ is defined as $\frac{1}{K} \sum_{n=1}^{K}\left|X_{i n}-X_{j n}\right|$, where $K$ counts the sectors/periods and $X$ stands for physical capital, human capital, inflation, trade, FDI, or output structure. Source: Own calculations.

Table 10

Univariate determinants of interprovince correlation of supply shocks, Maoist period.

\begin{tabular}{|c|c|c|c|c|}
\hline & \multicolumn{2}{|c|}{ 1955-1965 } & \multicolumn{2}{|c|}{ 1966-1977 } \\
\hline & 0 & $z$ & 0 & $z$ \\
\hline Common-border dummy & $\begin{array}{l}0.029 \\
(0.032) \\
{[0.003]}\end{array}$ & $\begin{array}{l}0.051 \\
(0.063) \\
{[0.002]}\end{array}$ & $\begin{array}{l}0.039 \\
(0.044) \\
{[0.002]}\end{array}$ & $\begin{array}{l}0.047 \\
(0.056) \\
{[0.002]}\end{array}$ \\
\hline Railway (freight) distance [in 1000s km] & $\begin{array}{l}0.004 \\
(0.01) \\
{[0.000]}\end{array}$ & $\begin{array}{c}-0.001 \\
(0.022) \\
{[0.000]}\end{array}$ & $\begin{array}{c}-0.006 \\
(0.015) \\
{[0.001]}\end{array}$ & $\begin{array}{c}-0.006 \\
(0.019) \\
{[0.000]}\end{array}$ \\
\hline Economic size $\left[\log Y_{i}+\log Y_{j}\right]$ & $\begin{array}{l}0.022 \\
(0.026) \\
{[0.002]}\end{array}$ & $\begin{array}{l}0.043 \\
(0.052) \\
{[0.002]}\end{array}$ & $\begin{array}{l}0.005 \\
(0.036) \\
{[0.000]}\end{array}$ & $\begin{array}{l}0.012 \\
(0.046) \\
{[0.000]}\end{array}$ \\
\hline Dissimilarity of capital investment & $\begin{array}{c}-0.326 \\
(0.170) \\
{[0.011]}\end{array}$ & $\begin{array}{c}-0.599 \\
(0.336) \\
{[0.010]}\end{array}$ & $\begin{array}{c}-0.291 \\
(0.238) \\
{[0.005]}\end{array}$ & $\begin{array}{c}-0.358 \\
(0.304) \\
{[0.004]}\end{array}$ \\
\hline Dissimilarity of human capital & $\begin{array}{l}0.020 \\
(0.017) \\
{[0.004]}\end{array}$ & $\begin{array}{l}0.033 \\
(0.034) \\
{[0.003]}\end{array}$ & $\begin{array}{l}0.023 \\
(0.047) \\
{[0.001]}\end{array}$ & $\begin{array}{l}0.018 \\
(0.060) \\
{[0.000]}\end{array}$ \\
\hline Dissimilarity of inflation & $\begin{array}{c}-0.001 \\
(0.002) \\
{[0.001]}\end{array}$ & $\begin{array}{c}-0.002 \\
(0.003) \\
{[0.001]}\end{array}$ & $\begin{array}{c}-0.003 \\
(0.002) \\
{[0.005]}\end{array}$ & $\begin{array}{c}-0.003 \\
(0.003) \\
{[0.004]}\end{array}$ \\
\hline Standard deviation of fiscal deficit differentials & $\begin{array}{l}0.213 \\
(0.188) \\
{[0.004]}\end{array}$ & $\begin{array}{l}0.541 \\
(0.371) \\
{[0.007]}\end{array}$ & $\begin{array}{c}-0.695 \\
(0.529) \\
{[0.005]}\end{array}$ & $\begin{array}{c}-1.182^{*} \\
(0.674) \\
{[0.009]}\end{array}$ \\
\hline Observations & 325 & 325 & 325 & 325 \\
\hline
\end{tabular}

Robust standard errors in parentheses. Significance: ${ }^{* * *} 1 \%,{ }^{* *} 5 \%,{ }^{*} 10 \%$. Dependent variable: original correlations (o) and Fisher $z$-transformations (z). The commonborder and same-region dummies denote provinces that share a border and belong to the same region (East, Central or West), respectively. The coast and coast-interior dummies denote provinces that are both on the coast and where one is on the coast and the other in the interior, respectively. Distance is railway freight distance in kilometers. Economic size is the sum of the provincial GDPs in logs. Dissimilarity index of variable $X$ is defined as $\frac{1}{K} \sum_{n=1}^{K}\left|X_{i n}-X_{j n}\right|$, where $K$ counts the sectors/periods and $X$ stands for physical capital, human capital, inflation, trade, FDI, or output structure. Source: Own calculations. 
Table 11

Univariate determinants of interprovince correlation of supply shocks, reform period.

\begin{tabular}{|c|c|c|c|c|}
\hline & \multicolumn{2}{|l|}{ 1978-1991 } & \multicolumn{2}{|l|}{ 1992-2011 } \\
\hline & 0 & $z$ & 0 & $z$ \\
\hline Common-border dummy & $\begin{array}{l}0.022 \\
(0.037) \\
{[0.001]}\end{array}$ & $\begin{array}{l}0.045 \\
(0.045) \\
{[0.003]}\end{array}$ & $\begin{array}{l}0.125^{* * *} \\
(0.049) \\
{[0.017]}\end{array}$ & $\begin{array}{l}0.144^{* * * *} \\
(0.058) \\
{[0.016]}\end{array}$ \\
\hline Same-region dummy & $\begin{array}{l}0.039 \\
(0.029) \\
{[0.005]}\end{array}$ & $\begin{array}{l}0.058^{*} \\
(0.036) \\
{[0.007]}\end{array}$ & $\begin{array}{c}0.089^{* *} \\
(0.039) \\
{[0.013]}\end{array}$ & $\begin{array}{l}0.108^{* *} \\
(0.046) \\
{[0.015]}\end{array}$ \\
\hline Coast dummy & $\begin{array}{l}0.206^{* * *} \\
(0.046) \\
{[0.051]}\end{array}$ & $\begin{array}{l}0.257^{* * *} \\
(0.056) \\
{[0.054]}\end{array}$ & $\begin{array}{l}0.187^{* * *} \\
(0.062) \\
{[0.024]}\end{array}$ & $\begin{array}{l}0.252^{* * *} \\
(0.073) \\
{[0.031]}\end{array}$ \\
\hline Coast-interior dummy & $\begin{array}{l}0.033 \\
(0.070) \\
{[0.001]}\end{array}$ & $\begin{array}{l}0.052 \\
(0.085) \\
{[0.001]}\end{array}$ & $\begin{array}{l}-0.037 \\
(0.094) \\
{[0.000]}\end{array}$ & $\begin{array}{c}-0.052 \\
(0.110) \\
{[0.001]}\end{array}$ \\
\hline Railway (freight) distance [in 1000s km] & $\begin{array}{c}-0.022 \\
(0.013) \\
{[0.007]}\end{array}$ & $\begin{array}{c}-0.034^{*} \\
(0.016) \\
{[0.010]}\end{array}$ & $\begin{array}{l}0.003 \\
(0.018) \\
{[0.000]}\end{array}$ & $\begin{array}{l}0.003 \\
(0.021) \\
{[0.000]}\end{array}$ \\
\hline Economic size $\left[\log Y_{i}+\log Y_{j}\right]$ & $\begin{array}{l}0.117^{* * *} \\
(0.030) \\
{[0.038]}\end{array}$ & $\begin{array}{l}0.135^{* * *} \\
(0.037) \\
{[0.035]}\end{array}$ & $\begin{array}{l}0.034 \\
(0.035) \\
{[0.002]}\end{array}$ & $\begin{array}{l}0.051 \\
(0.041) \\
{[0.004]}\end{array}$ \\
\hline Dissimilarity of capital investment & $\begin{array}{l}-0.205 \\
(0.240) \\
{[0.002]}\end{array}$ & $\begin{array}{c}-0.223 \\
(0.291) \\
{[0.002]}\end{array}$ & $\begin{array}{c}-1.171^{* * *} \\
\quad(0.371) \\
{[0.026]}\end{array}$ & $\begin{array}{l}-1.383^{* * *} \\
(0.435) \\
{[0.026]}\end{array}$ \\
\hline Dissimilarity of fixed assets investment & $\begin{array}{l}-1.725^{* * *} \\
(0.346) \\
{[0.062]}\end{array}$ & $\begin{array}{c}-2.077^{* * * *} \\
(0.419) \\
{[0.061]}\end{array}$ & $\begin{array}{c}-0.737^{* *} \\
(0.307) \\
{[0.015]}\end{array}$ & $\begin{array}{c}-0.835^{* *} \\
(0.360) \\
{[0.014]}\end{array}$ \\
\hline Dissimilarity of human capital & $\begin{array}{l}0.512 \\
(1.856) \\
{[0.000]}\end{array}$ & $\begin{array}{c}-0.188 \\
(2.249) \\
{[0.000]}\end{array}$ & $\begin{array}{c}-9.083^{* *} \\
(3.888) \\
{[0.014]}\end{array}$ & $\begin{array}{c}-10.247^{* *} \\
(4.563) \\
{[0.013]}\end{array}$ \\
\hline Dissimilarity of inflation & $\begin{array}{l}0.008 \\
(0.012) \\
{[0.001]}\end{array}$ & $\begin{array}{l}0.007 \\
(0.015) \\
{[0.001]}\end{array}$ & $\begin{array}{c}0.054^{*} \\
(0.028) \\
{[0.010]}\end{array}$ & $\begin{array}{c}0.064^{* *} \\
(0.033) \\
{[0.010]}\end{array}$ \\
\hline Standard deviation of fiscal deficit differentials & $\begin{array}{l}0.542 \\
(0.349) \\
{[0.006]}\end{array}$ & $\begin{array}{l}0.680 \\
(0.422) \\
{[0.007]}\end{array}$ & $\begin{array}{c}-0.308 \\
(0.779) \\
{[0.000]}\end{array}$ & $\begin{array}{c}-0.590 \\
(0.914) \\
{[0.001]}\end{array}$ \\
\hline Dissimilarity of output structure & $\begin{array}{l}0.070 \\
(0.076) \\
{[0.002]}\end{array}$ & $\begin{array}{l}0.092 \\
(0.092) \\
{[0.003]}\end{array}$ & $\begin{array}{l}0.102 \\
(0.208) \\
{[0.001]}\end{array}$ & $\begin{array}{l}0.117 \\
(0.244) \\
{[0.001]}\end{array}$ \\
\hline Dissimilarity of FDI & $\begin{array}{l}2.207 \\
(2.440) \\
{[0.002]}\end{array}$ & $\begin{array}{l}2.465 \\
(2.958) \\
{[0.002]}\end{array}$ & $\begin{array}{c}-0.143 \\
(0.199) \\
{[0.001]}\end{array}$ & $\begin{array}{c}-0.164 \\
(0.233) \\
{[0.001]}\end{array}$ \\
\hline Dissimilarity of trade & $\begin{array}{l}0.167 \\
(0.106) \\
{[0.007]}\end{array}$ & $\begin{array}{l}0.190 \\
(0.128) \\
{[0.006]}\end{array}$ & $\begin{array}{l}0.031 \\
(0.046) \\
{[0.001]}\end{array}$ & $\begin{array}{c}-0.051 \\
(0.054) \\
{[0.002]}\end{array}$ \\
\hline Observations & 378 & 378 & 378 & 378 \\
\hline
\end{tabular}

Robust standard errors in parentheses. Significance: ${ }^{* * *} 1 \%,{ }^{* *} 5 \%,{ }^{*} 10 \%$. Dependent variable: original correlations (o) and Fisher $z$-transformations (z). The commonborder and same-region dummies denote provinces that share a border and belong to the same region (East, Central or West), respectively. The coast and coast-interior dummies denote provinces that are both on the coast and where one is on the coast and the other in the interior, respectively. Distance is railway freight distance in kilometers. Economic size is the sum of the provincial GDPs in logs. Dissimilarity index of variable $X$ is defined as $\frac{1}{K} \sum_{n=1}^{K}\left|X_{i n}-X_{j n}\right|$, where $K$ counts the sectors/periods and $X$ stands for physical capital, human capital, inflation, trade, FDI, or output structure. Source: Own calculations.

To compute the index, we consider five broad sectors of the Chinese economy: primary sector (comprising agriculture, hunting, forestry, fishing, and mining and quarrying); construction; manufacturing; infrastructure services (transportation, post and telecommunications); and trade services (wholesale, retail and catering). ${ }^{15}$

Another potential source of asymmetric shocks is represented by local policy making. Dissimilarity of local policies is measured by means of two indicators. One captures the provincial divergence of fiscal policy while the other investigates heterogeneity in terms of inflation. Similar to Clark and van Wincoop (2001) and Poncet and Barthèlemy (2008), we use the standard deviation of provincial budget deficit differentials to measure the dissimilarity of fiscal policy (with annual budget deficits expressed as percentages of GDP). We capture provincial divergence in inflation as

$$
\frac{1}{T} \sum_{t=1}^{T}\left|G P I_{i, t}-G P I_{j, t}\right|
$$

(see also Poncet and Barthèlemy (2008)), where GPI $I_{i, t}$ is the general price index of the province $i$ during the period $t$ and $T$ is the subperiod time span.

A major source of divergence of business cycles can be the exposure to foreign trade and foreign direct investment. We measure the foreign trade dissimilarity as

$$
\frac{1}{T} \sum_{t=1}^{T} \mid \operatorname{Trade}_{i, t}-\text { Trade }_{j, t} \mid
$$

\footnotetext{
15 The data are taken from the Chinese national statistic year book.
} 
Table 12

Univariate determinants of interprovince correlation of demand shocks, Maoist period.

\begin{tabular}{|c|c|c|c|c|}
\hline & \multicolumn{2}{|c|}{ 1955-1965 } & \multicolumn{2}{|l|}{$1966-1977$} \\
\hline & 0 & $z$ & 0 & $z$ \\
\hline Common-border dummy & $\begin{array}{l}0.011 \\
(0.059) \\
{[0.000]}\end{array}$ & $\begin{array}{l}0.007 \\
(0.068) \\
{[0.000]}\end{array}$ & $\begin{array}{c}0.159^{* * * *} \\
(0.054) \\
{[0.023]}\end{array}$ & $\begin{array}{c}0.171^{\text {**** }} \\
(0.062) \\
{[0.023]}\end{array}$ \\
\hline Railway (freight) distance [in 1000s km] & $\begin{array}{l}0.001 \\
(0.020) \\
{[0.000]}\end{array}$ & $\begin{array}{l}0.002 \\
(0.024) \\
{[0.000]}\end{array}$ & $\begin{array}{c}-0.104^{* * *} \\
(0.018) \\
{[0.094]}\end{array}$ & $\begin{array}{c}-0.114^{* * *} \\
(0.021) \\
{[0.087]}\end{array}$ \\
\hline Economic size $\left[\log Y_{i}+\log Y_{j}\right]$ & $\begin{array}{c}-0.051 \\
(0.048) \\
{[0.003]}\end{array}$ & $\begin{array}{c}-0.052 \\
(0.056) \\
{[0.003]}\end{array}$ & $\begin{array}{c}0.118^{* * * *} \\
(0.044) \\
{[0.022]}\end{array}$ & $\begin{array}{c}0.129^{* * * *} \\
(0.050) \\
{[0.020]}\end{array}$ \\
\hline Dissimilarity of capital investment & $\begin{array}{c}-0.019 \\
(0.315) \\
{[0.000]}\end{array}$ & $\begin{array}{c}-0.060 \\
(0.366) \\
{[0.000]}\end{array}$ & $\begin{array}{c}-1.091^{* * *} \\
{[0.042]} \\
{[0.042]}\end{array}$ & $\begin{array}{c}-1.215^{* * *} \\
(0.333) \\
{[0.040]}\end{array}$ \\
\hline Dissimilarity of human capital & $\begin{array}{c}-0.006 \\
(0.032) \\
{[0.000]}\end{array}$ & $\begin{array}{c}-0.008 \\
(0.037) \\
{[0.000]}\end{array}$ & $\begin{array}{l}0.063 \\
(0.059) \\
{[0.004]}\end{array}$ & $\begin{array}{c}-0.068 \\
(0.067) \\
{[0.003]}\end{array}$ \\
\hline Dissimilarity of inflation & $\begin{array}{c}-0.003 \\
(0.003) \\
{[0.003]}\end{array}$ & $\begin{array}{c}-0.003 \\
(0.003) \\
{[0.003]}\end{array}$ & $\begin{array}{c}-0.003 \\
(0.003) \\
{[0.003]}\end{array}$ & $\begin{array}{c}-0.003 \\
(0.003) \\
{[0.003]}\end{array}$ \\
\hline Standard deviation of fiscal deficit differentials & $\begin{array}{l}0.200 \\
(0.347) \\
{[0.001]}\end{array}$ & $\begin{array}{l}0.209 \\
(0.404) \\
{[0.001]}\end{array}$ & $\begin{array}{c}-0.750 \\
(0.661) \\
{[0.004]}\end{array}$ & $\begin{array}{c}-0.913 \\
(0.754) \\
{[0.005]}\end{array}$ \\
\hline Observations & 325 & 325 & 325 & 325 \\
\hline
\end{tabular}

Robust standard errors in parentheses. Significance: ${ }^{* * *} 1 \%,{ }^{* *} 5 \%,{ }^{*} 10 \%$. Dependent variable: original correlations (o) and Fisher $z$-transformations (z). The commonborder and same-region dummies denote provinces that share a border and belong to the same region (East, Central or West), respectively. The coast and coast-interior dummies denote provinces that are both on the coast and where one is on the coast and the other in the interior, respectively. Distance is railway freight distance in kilometers. Economic size is the sum of the provincial GDPs in logs. Dissimilarity index of variable $X$ is defined as $\frac{1}{K} \sum_{n=1}^{K}\left|X_{i n}-X_{j n}\right|$, where $K$ counts the sectors/periods and $X$ stands for physical capital, human capital, inflation, trade, FDI, or output structure. Source: Own calculations.

where Trade $_{i, t}$ corresponds to the percentage share of foreign trade in GDP of province $i$ during period $t$ and $T$ is the sub-period time span. An analogous formula is used for FDI dissimilarity.

Finally, differences in factor endowments can also play a role in explaining the degree of business-cycle synchronization. We consider two factors of production: investments in human capital and fixed-assets. Investment in human capital is measured as secondary and higher education enrolment rates (i.e. the ratio of the total secondary and higher education enrolment to the population). Investment in physical capital is expressed as a percentage of GDP. For the pre-1978 period, we only have public investment (private investment during this period is likely to be very low or zero). After 1978, the data distinguish between total investment in physical capital (including public investment) and public investment only. For the general regressions, we include only total investment, whereas we use both types of investment in the univariate regressions. Both investments (human and physical capital) are entered as dissimilarity indexes computed in the same way as those for production structures, inflation and trade discussed above.

Thus, we estimate the following regressions for correlation of supply or demand shocks between all Chinese provinces for the four sub-periods

$$
\rho_{i j \tau}^{k, f}=\mathbf{X}_{i j \tau} \beta^{k, f}+\mu_{i j \tau}^{k, f}
$$

The dependent variable is either the correlation of supply and demand shocks $(k=S, D)$ or its Fisher $z$-transformation (denoted by superscript $f=0, z$, respectively). $\mathbf{X}$ is the vector of explanatory variables discussed above and $\beta^{k f}$ is the coefficient vector to be estimated. All variables are taken as average values for the respective sub-period. We first include all variables in a multivariate regression. Alternatively, we consider separate relationships between correlation of shocks and the various potential determinants, one explanatory variable at a time. The standard errors are robust to heteroskedasticity.

\subsection{Empirical results}

Tables 6 to 9 present the general regression results (with all variables) for each sub-period, for the correlations of shocks and their Fisher- $z$ transformations. The main finding concerning supply shocks during the Maoist period (Table 6) is that hardly any of the variables explain the interprovincial correlations of supply shocks in China. The overall explanatory power of the regressions estimated for this period is extremely low: the joint F-test is only significant for the second regression (with Fisher $z$-transformation for 19551965). The only gravity variable that appears to play any role is the dummy for coastal regions in 1955-1965 and its sign goes against our expectations: provinces located along the coast display lower symmetry of shocks than the rest. The dissimilarity in investment in physical capital lowers the correlation of supply shocks, significantly so during the early part of the Maoist period. Overall, economic determinants seem to matter little for business cycle synchronization during the Maoist era.

The picture becomes clearer during the reform period (Table 7). Adjacent regions and those located on the coast display higher correlations of supply shocks (however, the common-border dummy is only significant during the 1992-1911 period). The dissimilarity in investment in physical capital continues to lower the correlation of supply shocks during both sub-periods, in line with expectations: regions with different patterns of investment have their business cycles less synchronized. 
Table 13

Univariate determinants of interprovince correlation of demand shocks, reform period.

\begin{tabular}{|c|c|c|c|c|}
\hline & \multicolumn{2}{|l|}{ 1978-1991 } & \multicolumn{2}{|l|}{ 1992-2011 } \\
\hline & 0 & $z$ & 0 & $z$ \\
\hline Common-border dummy & $\begin{array}{c}0.019 \\
(0.037) \\
{[0.00109]}\end{array}$ & $\begin{array}{l}0.041 \\
(0.046) \\
{[0.0021]}\end{array}$ & $\begin{array}{l}0.012 \\
(0.017) \\
{[0.001]}\end{array}$ & $\begin{array}{l}0.026 \\
(0.035) \\
{[0.001]}\end{array}$ \\
\hline Same-region dummy & $\begin{array}{c}-0.022 \\
(0.029) \\
{[0.002]}\end{array}$ & $\begin{array}{c}-0.030 \\
(0.037) \\
{[0.008]}\end{array}$ & $\begin{array}{l}0.003 \\
(0.013) \\
{[0.000]}\end{array}$ & $\begin{array}{l}0.020 \\
(0.028) \\
{[0.001]}\end{array}$ \\
\hline Coast dummy & $\begin{array}{c}-0.016 \\
(0.046) \\
{[0.000]}\end{array}$ & $\begin{array}{c}-0.023 \\
(0.059) \\
{[0.000]}\end{array}$ & $\begin{array}{c}-0.038^{*} \\
(0.021) \\
{[0.009]}\end{array}$ & $\begin{array}{c}-0.068 \\
(0.044) \\
{[0.006]}\end{array}$ \\
\hline Coast-interior dummy & $\begin{array}{l}0.041 \\
(0.069) \\
{[0.001]}\end{array}$ & $\begin{array}{l}0.090 \\
(0.087) \\
{[0.003]}\end{array}$ & $\begin{array}{c}-0.026 \\
(0.032) \\
{[0.002]}\end{array}$ & $\begin{array}{c}-0.074 \\
(0.066) \\
{[0.003]}\end{array}$ \\
\hline Railway (freight) distance [in 1000s km] & $\begin{array}{c}-0.022^{*} \\
(0.013) \\
{[0.007]}\end{array}$ & $\begin{array}{c}-0.033^{* *} \\
(0.017) \\
{[0.010]}\end{array}$ & $\begin{array}{c}-0.016^{* * *} \\
(0.006) \\
{[0.018]}\end{array}$ & $\begin{array}{c}-0.034^{* * * *} \\
(0.013) \\
{[0.019]}\end{array}$ \\
\hline Economic size $\left[\log Y_{i}+\log Y_{j}\right]$ & $\begin{array}{c}-0.116^{* * * *} \\
{[0.030)} \\
{[0.039]}\end{array}$ & $\begin{array}{c}-0.143^{* * * *} \\
(0.038) \\
{[0.037]}\end{array}$ & $\begin{array}{c}-0.025^{\text {*** }} \\
(0.012) \\
{[0.012]}\end{array}$ & $\begin{array}{c}-0.057^{\text {*** }} \\
(0.025) \\
{[0.014]}\end{array}$ \\
\hline Dissimilarity of capital investment & $\begin{array}{l}0.328 \\
(0.235) \\
{[0.005]}\end{array}$ & $\begin{array}{l}0.335 \\
(0.299) \\
{[0.003]}\end{array}$ & $\begin{array}{c}-0.015 \\
(0.128) \\
{[0.000]}\end{array}$ & $\begin{array}{c}-0.142 \\
(0.265) \\
{[0.001]}\end{array}$ \\
\hline Dissimilarity of fixed assets investment & $\begin{array}{c}0.721^{* * *} \\
(0.348) \\
{[0.011]}\end{array}$ & $\begin{array}{c}0.862^{* * *} \\
(0.443) \\
{[0.010]}\end{array}$ & $\begin{array}{l}0.027 \\
(0.105) \\
{[0.000]}\end{array}$ & $\begin{array}{c}-0.003 \\
(0.218) \\
{[0.000]}\end{array}$ \\
\hline Dissimilarity of human capital & $\begin{array}{c}-0.958 \\
(1.820) \\
{[0.001]}\end{array}$ & $\begin{array}{l}-1.09 \\
(2.32) \\
{[0.001]}\end{array}$ & $\begin{array}{c}-2.108 \\
(1.325) \\
{[0.007]}\end{array}$ & $\begin{array}{c}-4.550^{*} \\
(2.750) \\
{[0.007]}\end{array}$ \\
\hline Dissimilarity of inflation & $\begin{array}{c}0.040^{\text {**** }} \\
(0.012) \\
{[0.029]}\end{array}$ & $\begin{array}{c}0.053^{\text {**** }} \\
(0.015) \\
{[0.032]}\end{array}$ & $\begin{array}{l}0.006 \\
(0.010) \\
{[0.001]}\end{array}$ & $\begin{array}{l}0.001 \\
(0.020) \\
{[0.000]}\end{array}$ \\
\hline Standard deviation of fiscal deficit differentials & $\begin{array}{c}-0.694^{* *} \\
(0.341) \\
{[0.011]}\end{array}$ & $\begin{array}{c}-0.921^{* *} \\
(0.434) \\
{[0.012]}\end{array}$ & $\begin{array}{c}-0.151 \\
(0.264) \\
{[0.001]}\end{array}$ & $\begin{array}{c}-0.249 \\
(0.549) \\
{[0.001]}\end{array}$ \\
\hline Dissimilarity of output structure & $\begin{array}{c}-0.150^{* *} \\
(0.074) \\
{[0.011]}\end{array}$ & $\begin{array}{c}-0.200^{* *} \\
(0.094) \\
{[0.012]}\end{array}$ & $\begin{array}{c}-0.065 \\
(0.071) \\
{[0.002]}\end{array}$ & $\begin{array}{c}-0.191 \\
(0.146) \\
{[0.005]}\end{array}$ \\
\hline Dissimilarity of FDI & $\begin{array}{l}0.257 \\
(2.397) \\
{[0.000]}\end{array}$ & $\begin{array}{l}0.288 \\
(3.050) \\
{[0.000]}\end{array}$ & $\begin{array}{c}-0.047 \\
(0.068) \\
{[0.001]}\end{array}$ & $\begin{array}{c}-0.134 \\
(0.140) \\
{[0.002]}\end{array}$ \\
\hline Dissimilarity of trade & $\begin{array}{c}-0.151 \\
(0.104) \\
{[0.006]}\end{array}$ & $\begin{array}{c}-0.185 \\
(0.132) \\
{[0.005]}\end{array}$ & $\begin{array}{c}-0.013 \\
(0.016) \\
{[0.002]}\end{array}$ & $\begin{array}{c}-0.043 \\
(0.033) \\
{[0.005]}\end{array}$ \\
\hline Observations & 378 & 378 & 378 & 378 \\
\hline
\end{tabular}

Robust standard errors in parentheses. Significance: ${ }^{* * *} 1 \%{ }^{* *} 5 \%,{ }^{*} 10 \%$. Dependent variable: original correlations (o) and Fisher $z$-transformations (z). The commonborder and same-region dummies denote provinces that share a border and belong to the same region (East, Central or West), respectively. The coast and coast-interior dummies denote provinces that are both on the coast and where one is on the coast and the other in the interior, respectively. Distance is railway freight distance in kilometers. Economic size is the sum of the provincial GDPs in logs. Dissimilarity index of variable $X$ is defined as $\frac{1}{K} \sum_{n=1}^{K}\left|X_{i n}-X_{j n}\right|$, where $K$ counts the sectors/periods and $X$ stands for physical capital, human capital, inflation, trade, FDI, or output structure. Source: Own calculations.

The regression results for the correlations of demand shocks are presented in Tables 8-9. Again, essentially none of the included variables explain the similarity between provincial shocks during the early Maoist period (and again, the explanatory variables are not jointly significant for this period). During the later Maoist period, 1966-1977, we see that the correlation of shocks falls with distance. Much clearer picture again emerges during the reform period, especially the early sub-period, 1978-1991. The degree of correlation of demand shocks again falls with distance (more so during the early reform period). Regions located on the coast tend to encounter similar shocks during the early reform period. However, this is counterbalanced by the negative coefficient estimated for the same-region dummy during the same period. This surprising result may reflect a dichotomy between the regional centers and their surrounding rural areas. Economic size appears to lower the symmetry of shocks during the early reform period: two relatively large provinces would be expected to display a lower degree of symmetry of demand shocks than two small provinces. Dissimilarity of investment in physical capital no longer affects synchronization of shocks, whereas dissimilarity in human capital appears to lower synchronization of shocks during the late reform period, 1992-1911.

Several variables are notable for being consistently insignificant: dissimilarity indexes with respect to the output structures, exposure to trade and incoming FDI apparent to have no impact on the symmetry of supply or demand shocks. This is somewhat surprising, especially for trade and FDI, given the extraordinary importance of external economic relations for the post-1978 economic development (Huang (2011), for example, finds that exposure to FDI is an important determinant of economic growth of Chinese regions). A possible explanation of this absence is that the shocks attributable to foreign trade and FDI affect most of China in much the same way (or else that their effects quickly spillover across regions).

Some of the variables included in the preceding regressions are likely to be collinear with each other and this could explain their low significance. Therefore, in Tables 10-13, we report the results of univariate regressions between the correlations of supply and demand shocks, respectively, and each variable considered. Few explanatory variables appear significant during the Maoist period again. Nevertheless, common border, distance and output size shape the correlation of demand shocks during the late Maoist period: demand shocks become less symmetric with distance while their similarity is higher for adjacent and for larger provinces. Provinces sharing a common border, those located in the same region and those on the coast also appear more similar during the reform period 
(though the coefficients are not always significant). The effect of distance is similarly negative but it is not always significant. Economic size is not a significant determinant of supply shocks whereas it appears negatively related to the correlation of demand shocks during the reform period.

\section{Conclusion}

The Chinese society has experienced numerous dramatic changes during the last five decades: the communist take-over, the upheavals of the Great Leap Forward and Cultural Revolution, and finally economic liberalization and opening up to the outside world and the rapid growth that this has generated. In this paper, we document the impact of these changes on the Chinese regional economies and on the degree of economic integration among them. The picture that our results paint is mixed: as the reforms progress, Chinese provinces encounter increasingly symmetric demand shocks but also increasingly asymmetric supply shocks. This is potentially worrying: supply shocks lead to permanent economic differentials, unlike demand shocks, and therefore their falling similarity may undermine the stability of Chinese economic integration in the future. This may translate into growing economic and political tensions in the future, especially if appropriate adjustment channels are not introduced (for example, greater liberalization of migration between provinces). The experience of countries such as Belgium, Spain or Czechoslovakia demonstrates the dangers that growing economic divergence can pose serious danger for political unity of countries, especially ethnically diverse ones.

We relate the interprovincial correlations of supply and demand shocks to a broad range of economic variables but we again obtain at best mixed results. Little explains the synchronization of business cycles during the Maoist period, especially during its early part, 1955-1965. The limited explanatory power of economic factors should perhaps not be surprising, given that the Maoist period was dominated by politically-induced shocks of the Great Leap Forward and Cultural Revolution. During the reform period, factors typically associated with bilateral (interprovincial) trade matter, although their importance is not overwhelming. In particular, we find that the symmetry of both demand and supply shocks tends to fall with the distance between provinces and rises when provinces share a border or are located in the same region. We find also that provinces that experience similar patterns of investment in physical capital tend to encounter similar supply shocks. In contrast, similarity in investment in physical capital tends to make demand shocks less similar, possibly because investment behavior is itself driven by demand shocks. Hence, interprovincial trade increases the symmetry of both demand and supply shocks while investment in physical capital has opposite effects on supply and demand shocks. Finally, and rather surprisingly, we find little evidence that inward FDI and foreign trade affect the synchronization of demand or supply shocks, even though these are among the main factors highlighted as drivers of the recent Chinese growth.

Clearly, our analysis fails to account for a number of factors that can also contribute to the on-going divergence of permanent shocks in China. Chinese provinces may specialize in a relatively narrow range of products but our data only distinguish very coarse categories of output structure. Migration is an important channel mitigating asymmetric shocks but we do not have any (reliable) data on this. Moreover, migration in China is still highly constrained by the continued enforcement of the hukou system of household registration which limits mobility of workers and their entitlement to public goods. Finally, the role of the special economic zones deserves closer attention as the SEZs have effectively enjoyed a substantial head start over the rest of China. This, however, might require more disaggregate data than those that we have: the SEZs typically account only for a relatively small portion of the province in which they are located. Finally, the future will show whether supply shocks affecting Chinese regions will continue to diverge or whether this trend will be reversed.

\section{References}

Artis, M.J., Fidrmuc, J., \& Scharler, J. (2008). The transmission of business cycles. Economics of Transition, 16(3), 559-582.

Artis, M.J., \& Okubo, T. (2010). The UK intranational business cycle. Journal of Forecasting, 29(1-2), 71-93.

Artis, M.J., \& Okubo, T. (2011). The intranational business cycle in Japan. Oxford Economic Papers, 63(1), 111-133.

Babetskii, I. (2005). Trade integration and synchronization of shocks: Implications for EU enlargement. Economics of Transition, 13(1), 105-138.

Bai, T. (1981). Lun woguo jingji tizhi tiaozheng yu gaige de moshi wenti. In Jingji yanjiu bianjibu (Ed.), Guomin jingji tiaozheng yu jingji tizhi gaige (pp. 38-61). Jinan: Shandong renmin.

Baldwin, R., \& Taglioni, D. (2006). Gravity for dummies and dummies for gravity equations. Working Paper No. 12516. Cambridge, MA: NBER.

Baxter, M., \& Kouparitsas, M. (2005). Determinants of business cycle comovement: A robust analysis. Journal of Monetary Economics, 52, $113-157$.

Bayoumi, T., \& Eichengreen, B. (1993). Shocking aspects of European monetary integration. In F. Torres, \& F. Giavazzi (Eds.), Adjustment and growth in the European monetary union. Cambridge, UK: Cambridge University Press.

Blanchard, O.J., \& Quah, D. (1989). The dynamic effects of aggregate demand and supply disturbances. American Economic Review, 79(4), 655-673.

Calderon, C., Chong, A., \& Stein, E. (2007). Trade intensity and business cycle synchronization: Are developing countries any different? Journal of International Economics, 71(1), 2-21.

Chen, Q., Goh, C. -C., Sun, B., \& Xu, L.C. (2011). Market integration in China. World Bank Policy Research Working Paper 5630.

Clark, T., \& van Wincoop, E. (2001). Borders and business cycles. Journal of International Economics, 55, 59-85.

Darvas, Z., Rose, A.K., \& Szapary, G. (2005). Fiscal divergence and business cycle synchronization: Irresponsibility is idiosyncratic. NBER International Seminar on Macroeconomics 2005 (pp. 261-298). Cambridge: National Bureau of Economic Research.

de Haan, J., Inklaar, R., \& Jong-A-Pin, R. (2008a). Will business cycles in the euro area converge? A critical survey of empirical research. Journal of Economic Surveys, 22, 234-273.

de Haan, J., Inklaar, R., \& Jong-A-Pin, R. (2008b). Trade and business cycle synchronisation in OECD countries - A re-examination. European Economic Review, 52, $646-666$.

Fatás, A. (1997). EMU: Countries or regions? Lessons from the EMS experience. European Economic Review, 41, 743-751.

Fidrmuc, J. (2004). The endogeneity of the optimum currency area criteria, intra-industry trade, and EMU enlargement. Contemporary Economic Policy, 22(1), 1-12. Fidrmuc, J. (2013). Political economy of fiscal unions. CESifo Working Paper No. 4344. Munich: CESifo.

Fidrmuc, J., \& Korhonen, I. (2003). Similarity of supply and demand shocks between the euro area and the CEECs. Economic Systems, 27(3), 313-334.

Fidrmuc, J., \& Korhonen, I. (2006). Meta-analysis of the business cycle correlation between the euro area and the CEECs. Journal of Comparative Economics, 34(3), 518-537. 
Fleisher, B., Li, H.Z., \& Zhao, M.Q. (2009). Human capital, economic growth, and regional inequality in China. Journal of Development of Economics, 92, 215-231. Frankel, J.A., \& Rose, A. (1998). The endogeneity of the optimum currency area criteria. Quarterly Journal of Economics, 108, 1009-1025.

Gerlach-Kristen, P. (2009). Business cycle and inflation synchronisation in Mainland China and Hong Kong. International Review of Economics and Finance, 18, 404-418.

Herrerias, M.J., \& Ordoñez, J. (2012). New evidence on the role of regional clusters and convergence in China (1952-2008). China Economic Review, 23, 1120-1133.

Herrmann-Pillath, Libman, C.A., \& Yu, X. (2010). State and market integration in China: A spatial econometrics approach to 'local protectionism'. Frankfurt School Working Paper No. 137.

Huang, S. (2011). "Foreign Direct Investment and Regional Growth in China, Brunel University”. Mimeo.

Imbs, J. (1998). Fluctuations, bilateral trade and exchange rate regime. University of Lausanne, Working Paper.

Imbs, J. (2003). Co-fluctuations. DEEP Working Paper 98-19. University of Lausanne.

Imbs, J. (2004). Trade, finance, specialization and synchronization. Review of Economics and Statistics, 86(3), $723-734$.

Kalemli-Ozcan, S., Sorensen, B.E., Reshef, A., \& Yosha, O. (2001). Economic integration, industrial specialization, and the asymmetry of macroeconomic fluctuations. Journal of International Economics, 55, 107-137.

Krugman, P. (1991). Geography and trade. Cambridge: MIT Press.

Krugman, P. (1993). Lessons of Massachusetts for EMU. In F. Torres, \& F. Giavazzi (Eds.), Adjustment and growth in the European monetary union (pp. 241-261).

Cambridge, UK: Cambridge University Press and CEPR.

Lan, Y., \& Sylwester, K. (2010). Provincial fiscal positions and business cycle synchronization across China. Journal of Asian Economics, 2, 355-364.

Lee, P.K. (1998). Local economic protectionism in China's economic reform. Development Policy Review, 16, $281-303$.

Ma, J., \& Norregaard, J. (1998). China's fiscal decentralization. IMF (available at https://www.imf.org/external/pubs/ft/seminar/2000/idn/china.pdf).

Mundell, R.A. (1961). A theory of optimum currency areas. American Economic Review, 51, 657-665.

Poncet, S. (2005). The fragmentation of the Chinese domestic market. China Perspectives, 55.

Poncet, S., \& Barthelemy, J. (2008). China as an integrated area? Journal of Economic Integration, 23(4), $896-926$.

Stazka, A. (2006). Sources of real exchange rate fluctuations in central and eastern Europe - Temporary or permanent? Working paper no. 1876. Munich: CESifo.

Tang, K.K. (1998). Economic integration of the Chinese provinces: A business cycle approach. Journal of Economic Integration, 13, 549-570.

Xu, G. (2007). Business cycle accounting for the Chinese economy. Munich personal RePEc archive paper no.7050.

$\mathrm{Xu}, \mathrm{C}$. (2010). The institutional foundations of China's reforms and development. CEPR discussion paper no. 7654. London: CEPR. 